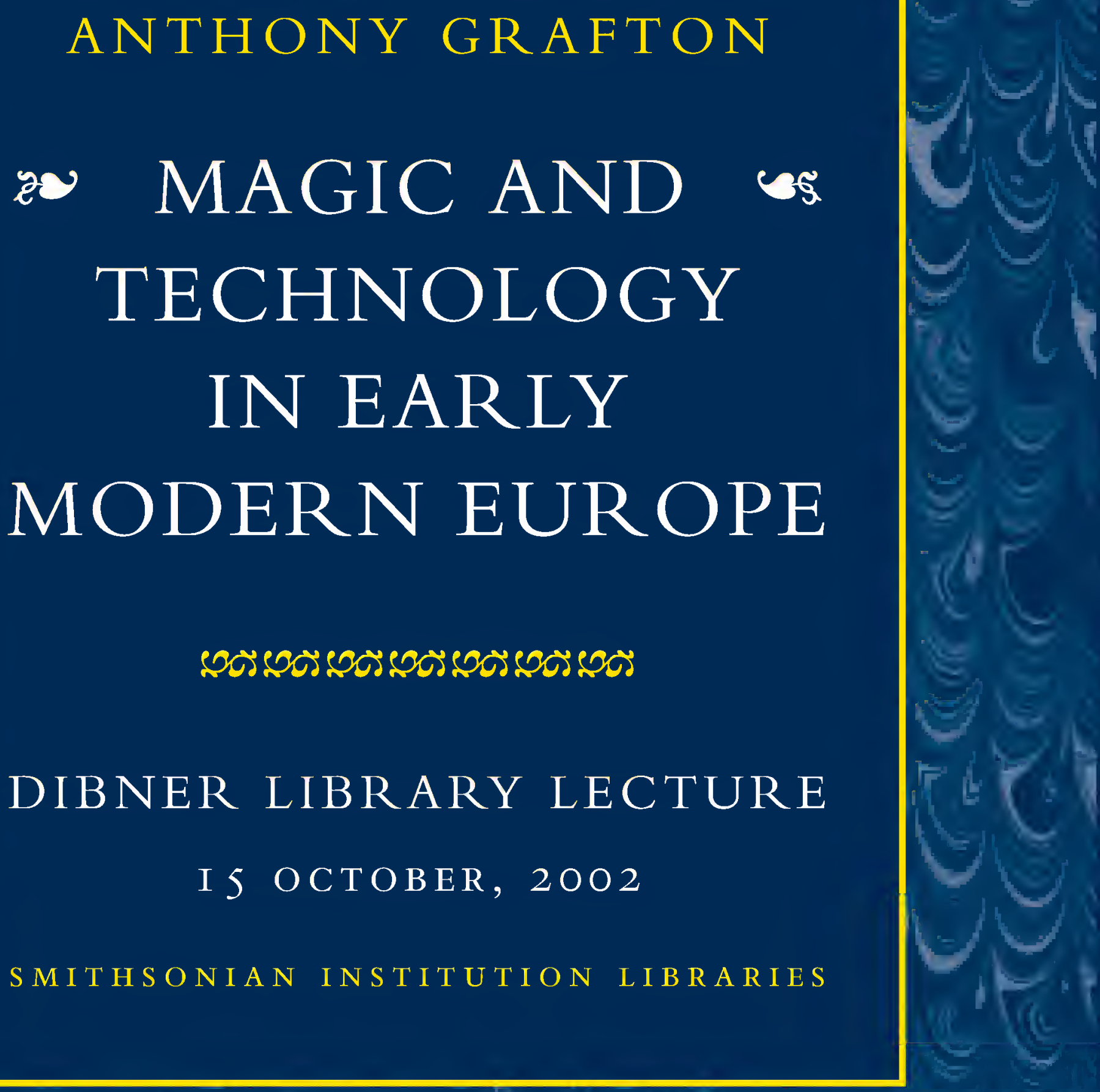

$$
\text { ANTHONY GRAFTON }
$$

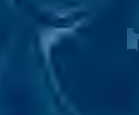

(a)
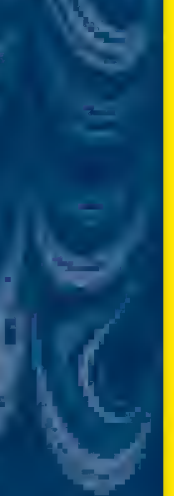

1

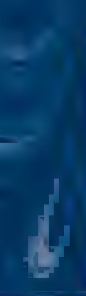

\title{
MODERN EUROPE
}

DIBNER LIBRARY LECTURE

$$
\text { I } 5 \text { OCTOBER, } 2002
$$

S M I THS O I A N INSTIT U T O N L IBRARIES 


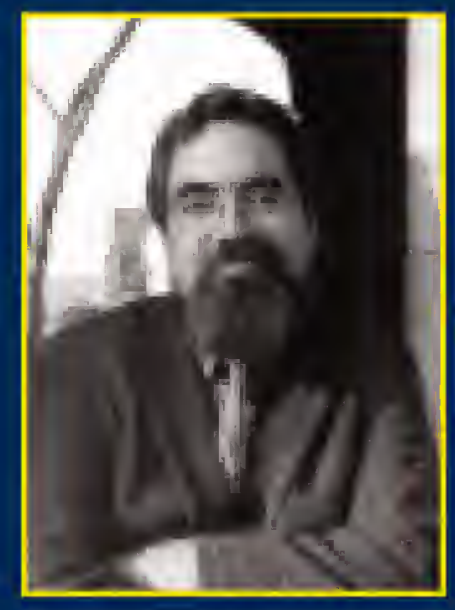

FROM AN INTERVIEW CONDUCTED WITH PROFESSOR ANTHONY GRAFTON ON THE PRINCETON UNIVERSITY CAMPUS:

You have published a great deal on a wide range of topics. What, in general terms, are the questions that interest you?

What really interests me is how people do things. I see that as the question that unifies my apparently completely disparate investigations of topics in Antiquity, in the Renaissance, in the Baroque, and in the modern age. More specifically, I've always been interested in how scholars did things in the past: how scholars studied documents, how they edited them, how they turned them into historical narratives and other kinds of publication; and I have a strong interest in similar questions about ancient and early modern scientists. I'm always less interested in intellectuals' grand theses-Is Providence ruling world history? - than I am in asking, What kind of methods did they use? How do we make sense of those methods historically? What sense did they make at the time? What work did those methods do that others wouldn't have? It's in pursuit of that kind of information that I've studied how people read books, how people wrote footnotes, how people built libraries. To answer these questions I've found myself doing lots of interdisciplinary work. Looking at archives, recreating institutions, reassembling networks of individuals who collaborated with one another. Doing the same kinds of things you would do to answer pretty much any historical question.

To view the entire transcript of this interview, go online to: http://his.princeton.edu/people/e52/anthony_grafton_inte .html 


\title{
MAGIC AND TECHNOLOGY IN EARLY MODERN EUROPE
}

\author{
3 \\ I N C OM M EMORATION OF T H E \\ T W E L F T H A N N U A L \\ D I B N E R L I B R A RY L E C T U R E S E R I E S
}





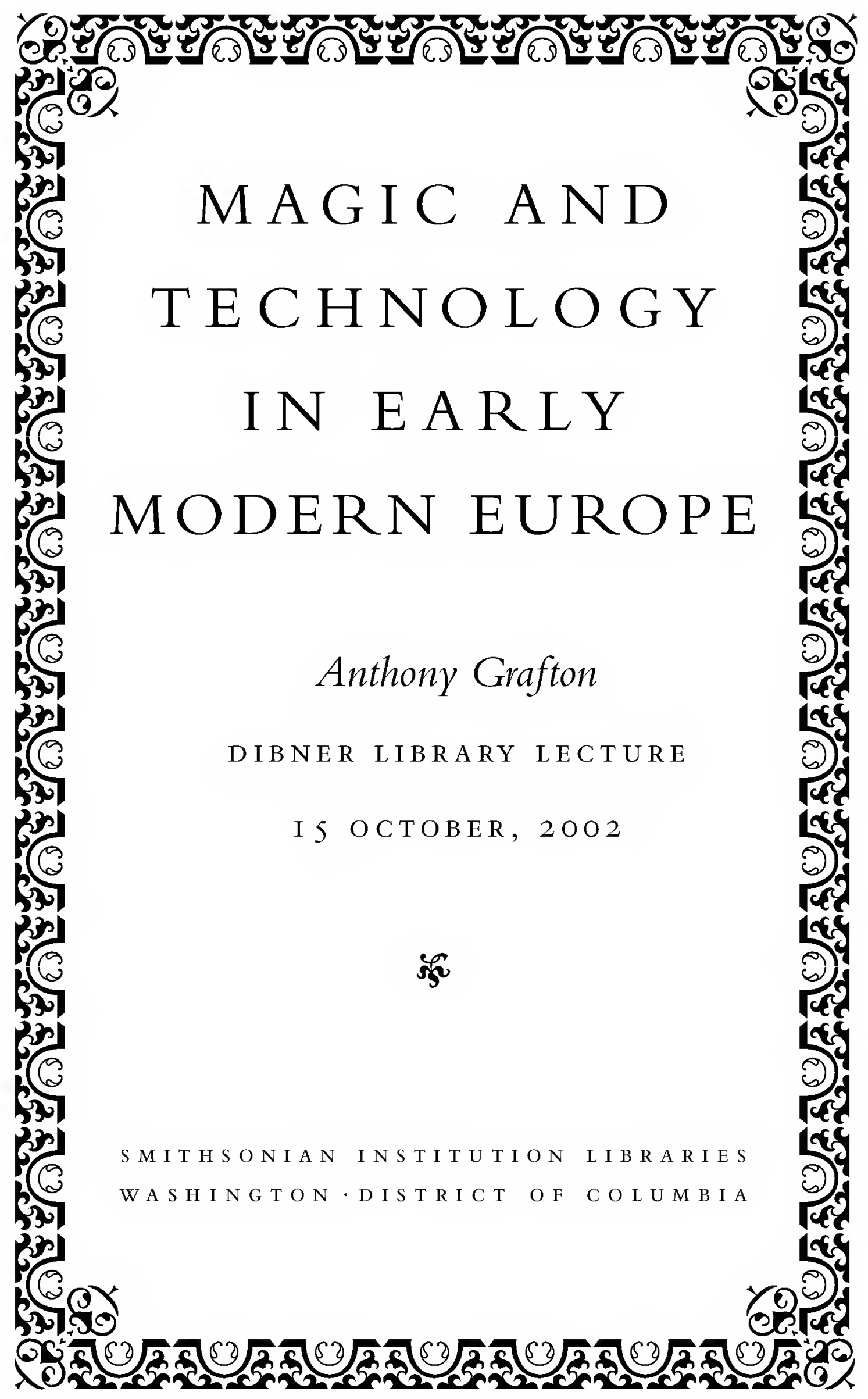


Published by Smithsonian Institution Libraries

Washington, DC 20013-7012

Text Copyright (C)2005 Anthony Grafton. All rights reserved.

All images from the Smithsonian Libraries' Dibner Library unless otherwise noted.

Anthony Grafton is the Dodge Professor of History and Director of Historical Studies at Princeton. He received his B.A., M.A., and Ph.D. from the University of Chicago and studied for a brief period at University College, London. Joining the Princeton faculty in 1975 , his many honors include the Behrman Prize for Achievement in the Humanities at Princeton, a visiting professorship at the École Normale Supèrieure in Paris, and fellowships from the Guggenheim Foundation and the Wissenschaftskolleg zu Berlin. He has delivered the J.H. Gray Lectures at Cambridge, the E.A. Lowe Lectures in Paleography and Kindred Subjects at Oxford, the Rothschild Lecture in the History of Science at Harvard, and the Meyer Schapiro Lectures at Columbia University. From 1998-99, he served as Warburg Professor in Hamburg, Germany. Author or editor of fourteen books, including a major two-volume study on Renaissance humanist Joseph Scaliger, Grafton focuses his scholarly attentions on the history of the classical tradition, particularly during the Renaissance. He also lectures on and writes about the history of science and the history of books and readers.

Edited by Robert Kearns

Designed and typeset by Marc Alain Meadows. Meadows Design Office, Inc., Washington, DC, www.mdomedia.com

LIBRARY OF CONGRESS CATALOGING-IN-PUBLICATION DATA

Grafton, Anthony.

Magic and technology in early modern Europe / by Anthony Grafton.Ist ed.

p. cm.- (Dibner library lecture)

Lecture held is October, 2002.

I. Technology - Europe - History - Addresses, essays, lectures. 2. Engineering - Europe - History - Addresses, essays, lectures. 3. Technology Philosophy - Addresses, essays, lectures. 4. Magic - Europe - Addresses, essays, lectures. I. Title. II. Series.

T26.AI.G73 2005

620'.0094'0903-dc22

2005013573 
MAGICAND TECHNOLOGY
IN EARLY MODERN EUROPE 


\section{F O R E W O R D}

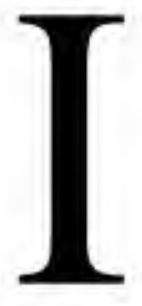

N Robert Heinlein's I 973 SCience fiction NOVEL Time Enough for Love, Lazarus Long, a continuously rejuvenated man (hence his name) who lives from I9I6 to 4272 , writes in his notebooks, "one man's magic is another man's engineering." And so it was in early modern Europe, according to Anthony Grafton, who presented the twelfth Dibner Library Lecture on October I 5, 2002. In his lively and entertaining presentation, Grafton showed how "the notion of a mathematical or artificial magic" rose from the ancient art of natural magic, embodied in such things as prayers and talismans, to the complex optical, hydraulic and mechanical devices that "not only rivaled, but actually outdid, the creative powers of nature itself." The machines and automata that emulated nature and the movement of living beings were so astonishing at first that the engineers had to seek independent authoritative testimony that the devices were the product of engineering skill, not occult practices.

Anthony Grafton, the Dodge Professor of History and Director of Historical Studies at Princeton University, has been dubbed "the Alchemist of Erudition" by the Chronicle of Higher Education for his ability to entice readers through dense subject matter with his sparkling prose. A regular contributor to The New York Review of Books, the New Republic, and The American Scholar, Grafton used the occasion of his Dibner Library Lecture to once again open the world of classical scholarship to the lay reader.

I am especially pleased to present Professor Grafton's essay in this series, because he vividly displays the reasons why the 
Smithsonian Libraries continues to promote the importance of historical study in the sciences. Most of the fifteenth-to-seventeenth century works he used to illuminate the intertwining of magic and engineering can be found among the numerous treasures of the Dibner Library of the History of Science and Technology. Those treasures are testimony to the long view that the collector and philanthropist Bern Dibner took when he began to acquire and preserve the 10,000 books and manuscripts that he donated from his Burndy Library to the Smithsonian Institution on the occasion of the United States Bicentennial celebration in 1976 .

Grown to 25,000 rare books and I,800 manuscript groups, the Dibner Library attracts scholars and students from around the world to mine its collections in engineering, transportation, chemistry, mathematics, physics, electricity, astronomy, and other fields. The Dibner Fund supports a variety of programs designed to share the riches and value of the Library with researchers and the general public and to promote the importance of continuing study of the history of science and technology.

We thank The Dibner Fund for its generous support of the Dibner Library Lecture series and its publications.

For more information, please see the home page of the Dibner Library of the History of Science and Technology at www. sil.si.edu/Libraries/Dibner/. To see Dr. Grafton's lecture and a list of all the other Dibner Library Lectures, go to www.sil.si .edu/exhibitions/lectures.htm.

Nancy E. Gwinn, Director

Smithsonian Institution Libraries

April 2005 


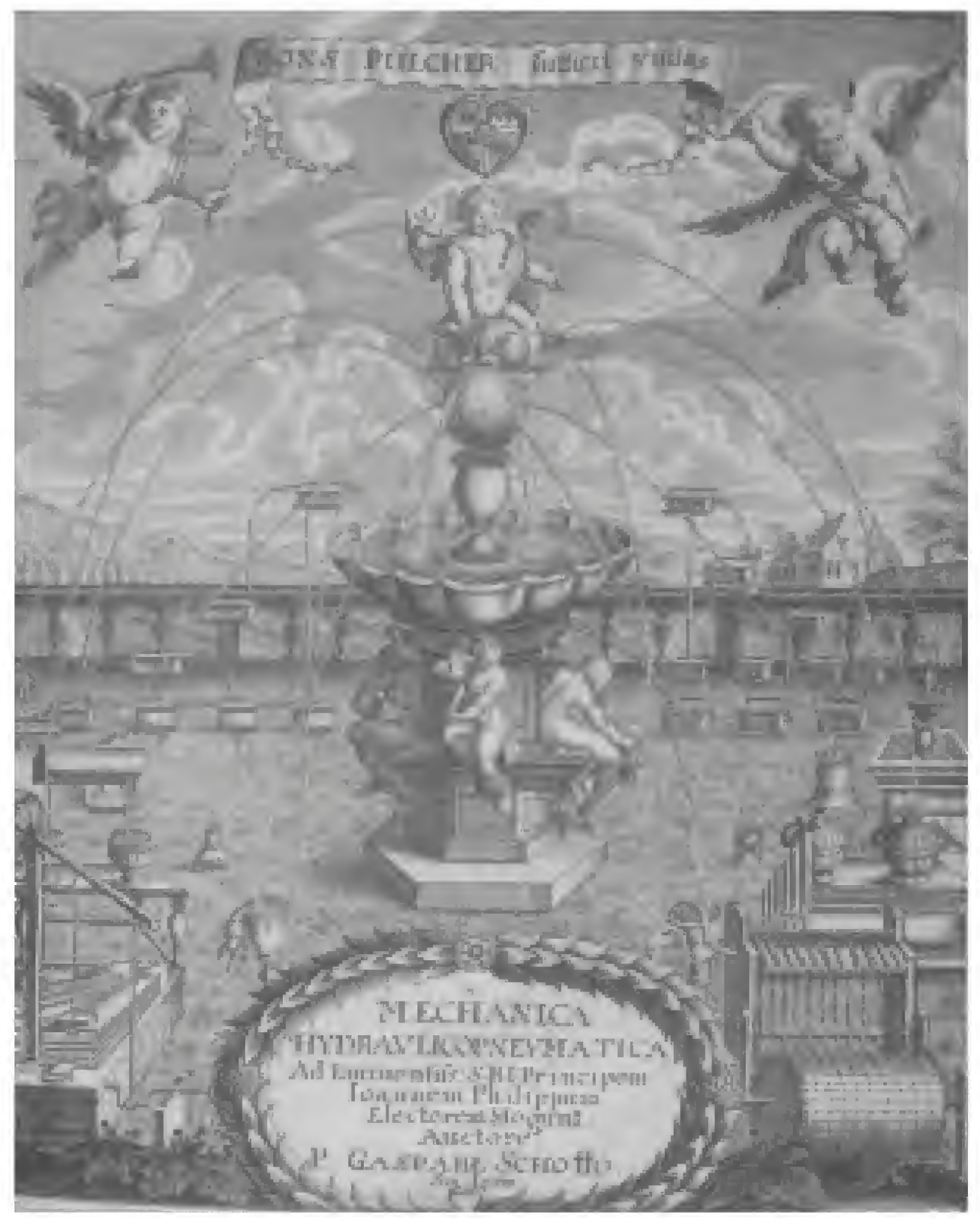

Title page of Schott's Mechanica hydraulico-pneumatica, I657. 


\section{MAGIC AND TECHNOLOGY IN EARLY MODERN EUROPE}

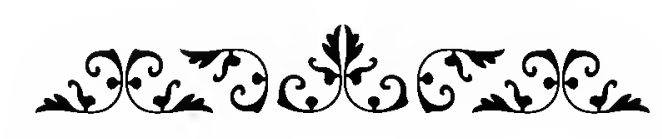

S

hortly after I650, a performer named Jean Royer appeared in the Piazza Navona at Rome. He stood next to the magnificent fountain of the four rivers, just created and unveiled by an unmatchable conceptual team, Athanasius Kircher and Gianlorenzo Bernini. In the baroque city's sunlit central theatre, as high-ranking prelates and noblewomen took the air in their sedan chairs, brilliantly devised hydraulic machinery forced powerful streams of water through a magnificent hollow rock. Stone river gods and animals so animated that they seemed to live and move presided over the scene - one so dramatic, even magical, that Pope Innocent X, the project's patron, became "ecstatic," as Saint Teresa did in her moments of levitation, when he first saw the water flow.

Standing next to the marvelous mechanical fountain, Royer challenged it. A professional regurgitator, he convoked slackjawed crowds in the piazza, swallowed gallons of water, and then sprayed out streams of whatever liquid the members of his audience asked for: perfumed oils, vinegar (we don't know if it was balsamic), even wine. Like the modern street performers who emulate statues in the same piazza, Royer played with the distinction between art and nature. And he did so, with incomparable 
elegance and boldness, next to the grandest sculptural complex of the time, which also, as a secular critical tradition made clear, played with that distinction. But Royer's performance was more dangerous than those that take place on Sundays nowadays. He played with the borders that separated magic from science and natural from demonic agency. In mid-seventeenth-century Rome, the citadel of the Counter-Reformation ecclesia triumphans, fountains could shoot attractive sprays of water into the air, but only priests could properly transform it into wine. The regurgitator's unnatural art naturally provoked suspicion - especially at a time when supposed episodes of witchcraft and demonic possession regularly troubled Catholic authorities.

Challenged to show that he did not rely on diabolic help, Royer found assistance from the fountain's intellectual designer, Kircher, and his friend and colleague Gaspar Schott. These brilliant Jesuits lived and worked in the order's central establishment, the Collegio Romano, not far from the Piazza Navona. Schott came over, watched Royer perform and brought him back to meet his colleague. In the privacy of Kircher's museum, Royer admitted that he swallowed small sponges soaked in the various liquors he produced and squeezed them with his teeth to give the illusion that he could make water into vinegar or wine. The liquors that came out of his mouth looked and smelled right; and, as he explained, naturally no one was willing to subject them to the definitive but difficult taste test. Kircher and Schott already knew about performances of this kind; a Protestant acquaintance in Nuremberg, Harsdörffer, had described and explained them in his own Delights of Physics and Mathematics. Accordingly, they felt no reluctance to provide Royer with a certificate, which explained that he achieved his results not by diabolic help but by natural means. Schott included Royer, the human being, as one 
of the hydraulic machines - along with clocks and automata that he described in a detailed, splendidly illustrated book in I657. ${ }^{\mathrm{I}}$

For Kircher and Schott, Royer's achievement illustrated something about magic. This fascinating but frightening pursuit, they argued, took two forms. On the one hand, learned magi practiced the ancient art of natural magic. Using the powers embodied in the heavens by the creator, pulling on the subtle cosmic web of influences that stretched down from the heavens and connecting stars and planets to stones and plants, parts of the body and sections of human life, they devised talismans and uttered prayers that warded off malign influences and brought down benign ones. These men, Kircher and Schott firmly believed, carried on a magic art that had its origins in ancient Egypt and that rested on true knowledge about the occult properties, the hidden sympathies and antipathies of all things in the universe. This same form of magic underpinned some of Kircher's own proudest inventions - like the sunflower clock, which turned with the sun, supposedly thanks to a universal magnetic force that kept it moving.

At the same time, however, magi also practiced a second art, which Kircher and Schott called "mathematical" or "artificial magic." Using optical, hydraulic and mechanical techniques, rather than stellar influences, they created devices that not only rivaled, but actually outdid, the creative powers of nature herself. Practitioners of this kind of magic - who included Dædalus, Archytas and Archimedes in ancient times, Johannes Regiomontanus and Kircher himself in more recent ones - had fashioned machines that flew and traveled under water, mirrors that burnt enemy ships to a crisp, fountains and automata that emulated the movements of living beings. 
The devices that Schott and Kircher assigned to the category of mathematical or artificial magic mostly look - to the modern reader - like the products of an alien, premodern sort of engineering technology. Many of them were vehicles of one sort or another, which moved without draught animals or oarsmen to propel them. Others, even eerier, actually seemed to be animated. And all of them embodied a single, complex set of propositions. They rested on the assumption that humans could analyze natural phenomena and reproduce them; more radically still, in the case of the automata, they implied that machines could replicate the motions of humans and animals. It was a short step from this view to the stronger one - one usually associated by historians with Descartes - that animals and humans were in fact machines, the latter of which happened to be inhabited by souls.

Human performers weren't the only ones who exemplified this mechanist, reductionist view of natural organisms. It also found expression in, for example, the vomiting lobsters that both Harsdörffer and Schott illustrated and described at length. This aesthetically irresistible organic machine proved beyond doubt that animals could be analyzed as mechanical systems. A cooked lobster, set across the rim of a pot of water, would draw the liquid upwards by capillary action - a phenomenon only recently identified in the mid-seventeenth century. If the larger part of the lobster lay outside the vase, it would then automatically transfer the water into a second vessel. The upshot of the experiment seemed clear to both men: a lobster was not only a complex monstrous being with claws but one of the simplest hydraulic machines, a siphon.

As Kircher and Schott examined the historical and textual record, they found many examples of mathematical magic especially in ancient Egypt. The same mastery of hydraulics and 


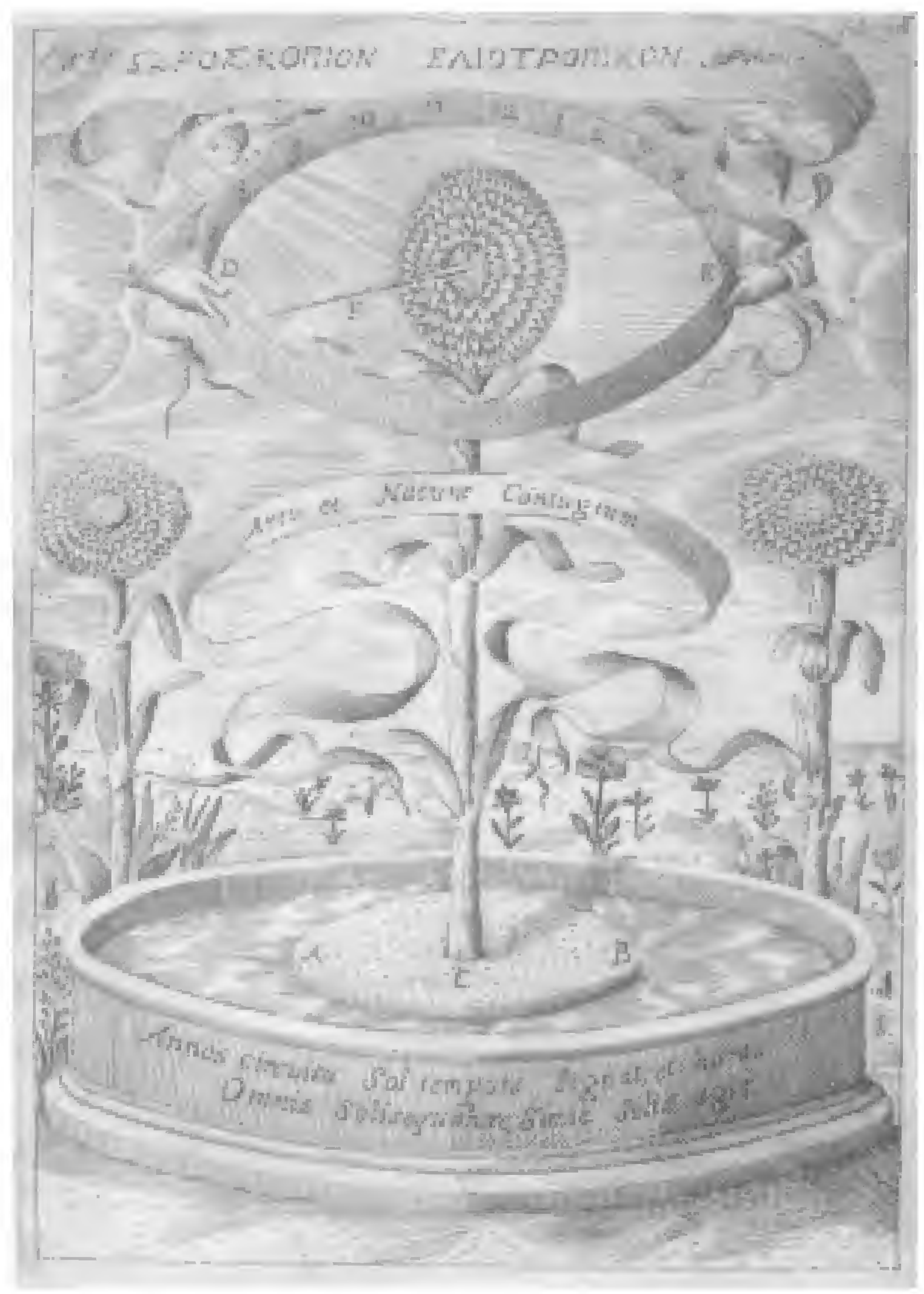

Kircher's sunflower clock, from his Magnes; sive, De arte magnetica, I64 I 


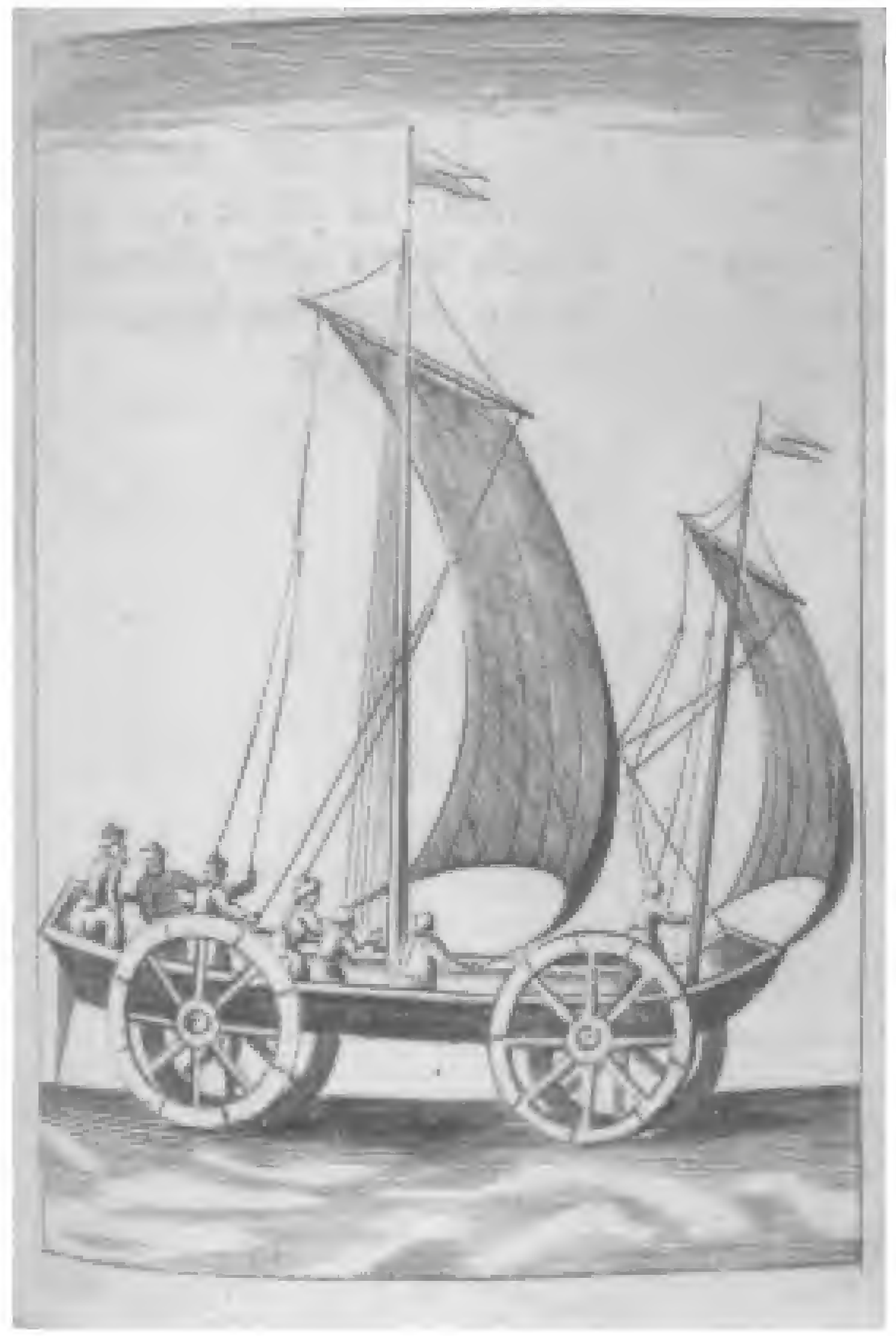

Wind-powered wagon from John Wilkins' Mathematicall magick, I 648 . 


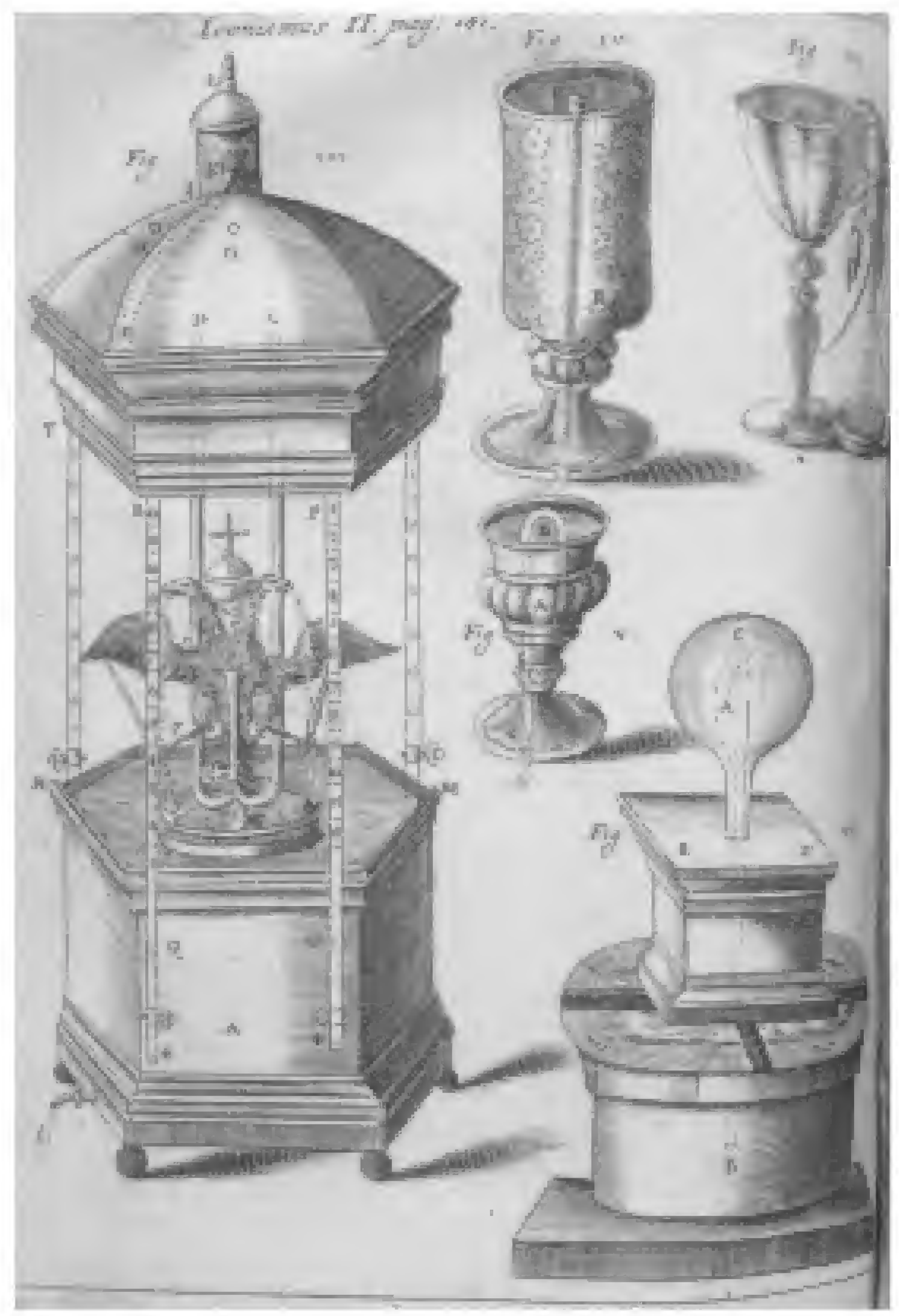

Vomiting lobster (figure IV) from Schott's

Mechanica hydraulico-pneumatica, I657. 


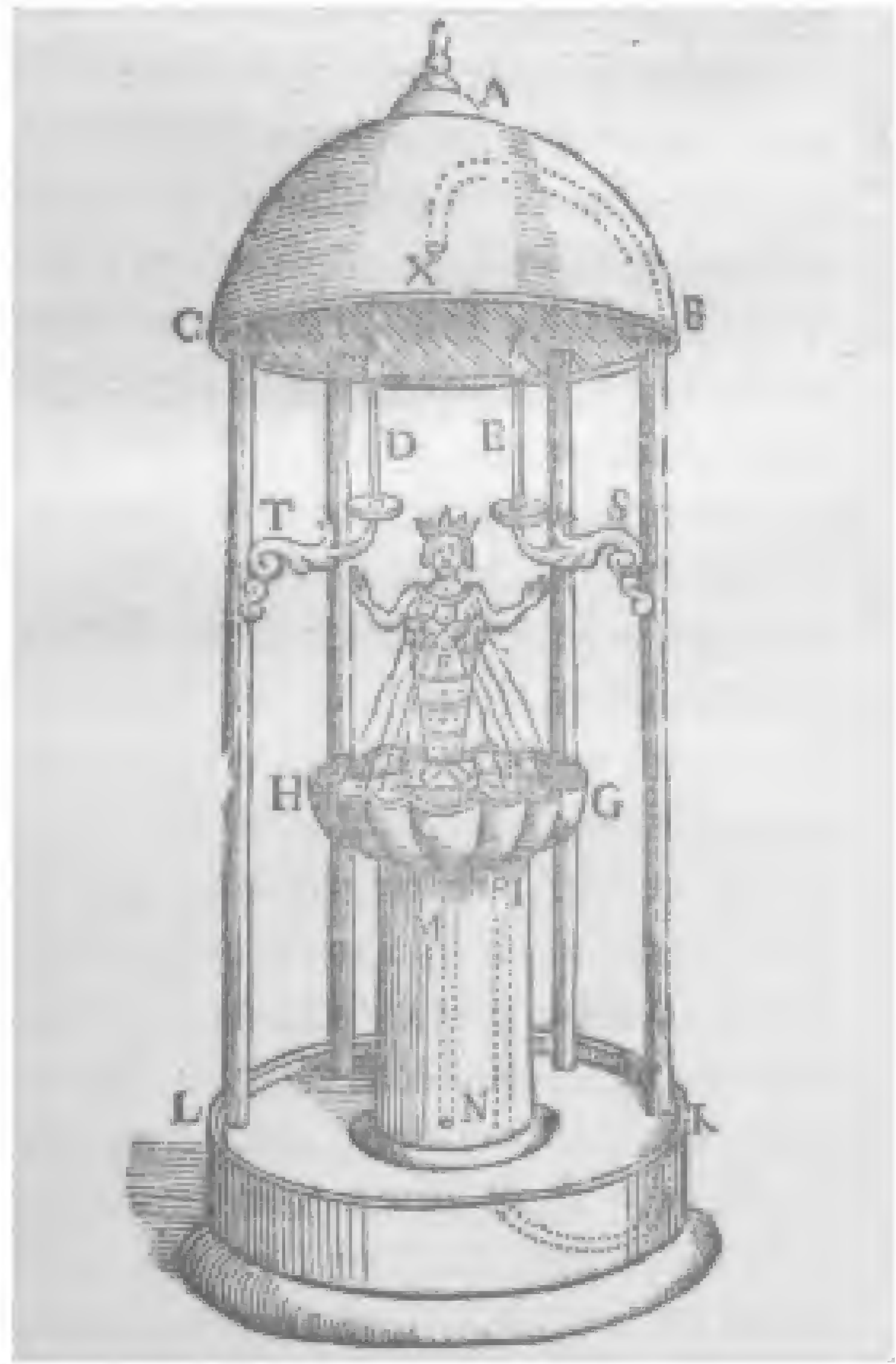

Mother of the Gods from Kircher's Physiologia Kircheriana experimentalis, $\mathbf{I} 680$. 
pneumatics exemplified by the machines in their own splendid museum had enabled the ancient Egyptians to create miraculous effects. Hermes Trismegistus, the supposedly Egyptian author of an influential set of dialogues about nature that Europeans long saw as the source from which Plato and later Greek philosophers drew their wisdom, had stated that the ancient Egyptians could draw demons down from the sky to inhabit statues, which could then move and speak. This claim both fascinated and worried Marsilio Ficino and other modern readers of Hermes. They saw it as a scary indication that Egyptian magic might have been genuinely demonic. Schott and Kircher, however, explained the apparently animated statues as mechanical devices. Mastery of a particular acoustical technology had enabled the Egyptians to introduce speaking-tubes into their statues. Knowledge of pneumatics and hydraulics, on the other hand, had allowed them to create a multi-breasted mother of the gods that poured out milk from every nipple, and statues of Isis and Osiris that seemed to move and even to pour libations. In the end, Kircher and Schott decided that all the achievements of Alexandrian technology the pneumatic and hydraulic machinery described by Heron of Alexandria - actually derived from the original mathematical magic of ancient Egypt. ${ }^{2}$

Kircher and Schott did not see themselves as exposing the ancient Egyptians as frauds. Rather, they insisted, the Egyptians had practiced a particular kind of magic, one that relied not on occult forces but on simple machines and lenses in order to mystify and to amaze. In making this argument, moreover, they were by no means isolated. Across the continent of Europe from the baroque theatre of wonders that was Rome, the sober Protestant John Wilkins devoted a treatise of his own to Mathematicall Magick. ${ }^{3}$ Like the Roman Jesuits, he described machines that could fly or 
navigate under water, carriages that moved without animals to draw them, and other automata. And like them, he illustrated his programmatic work, not only with designs that had already been shown to be successful, but also with his own plans for a carriage that could move, by air power, even with the wind against it, and a submarine that could stay under water for long periods.

Evidently, then, the identification of a particular, technological brand of magic was not simply a wild idea of the Roman Jesuits, who also developed the cat piano (a clavier whose keys, when played, drove nails into a set of imprisoned cats carefully chosen for their voices, a musical and non-lethal cat massacre, so Kircher explained, guaranteed to cure the most melancholic ruler of his lethargy). Rather, it reflected ideas and practices to be found in every part of seventeenth-century Europe - from the Paris of Marin Mersenne, who agreed that such devices could often produce the effects falsely claimed by the natural magicians he despised, to the Holland and London of Cornelis Drebbel, who amazed both his fellow countrymen and crowds of Britons with the submarine that traveled underwater from Tower Bridge to Greenwich - and that he used, when unable to obtain government support, to attract customers for a pub that he opened, since free trips in the river evidently induced a healthy thirst. Kircher and Schott belonged to a cosmopolitan network of aficionados: when they imagined that the ancient mathematician Archytas of Tarentum used a magnet to keep his artificial bird in the sky, they borrowed images and ideas from their Protestant friend Georg Philipp Harsdörffer in Nuremberg.

My purpose, in this lecture, is easily stated if harder to carry out. I hope to ask how this notion of a mathematical or artificial magic took shape, to identify the ideas and practices out of which it crystallized, and then to show how it became a central part of 


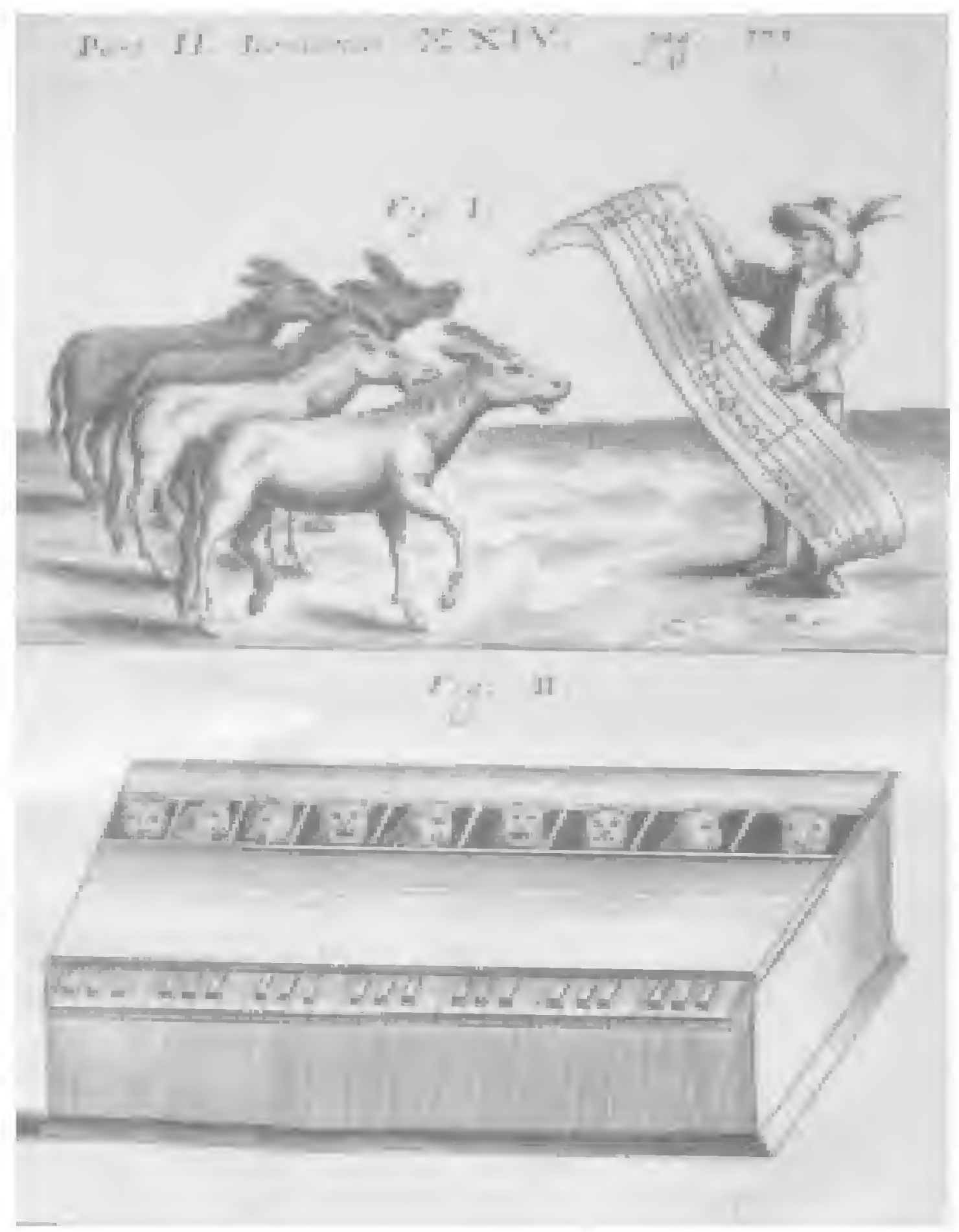

Cat piano (figure II) from Schott's Magia universalis, I657. 


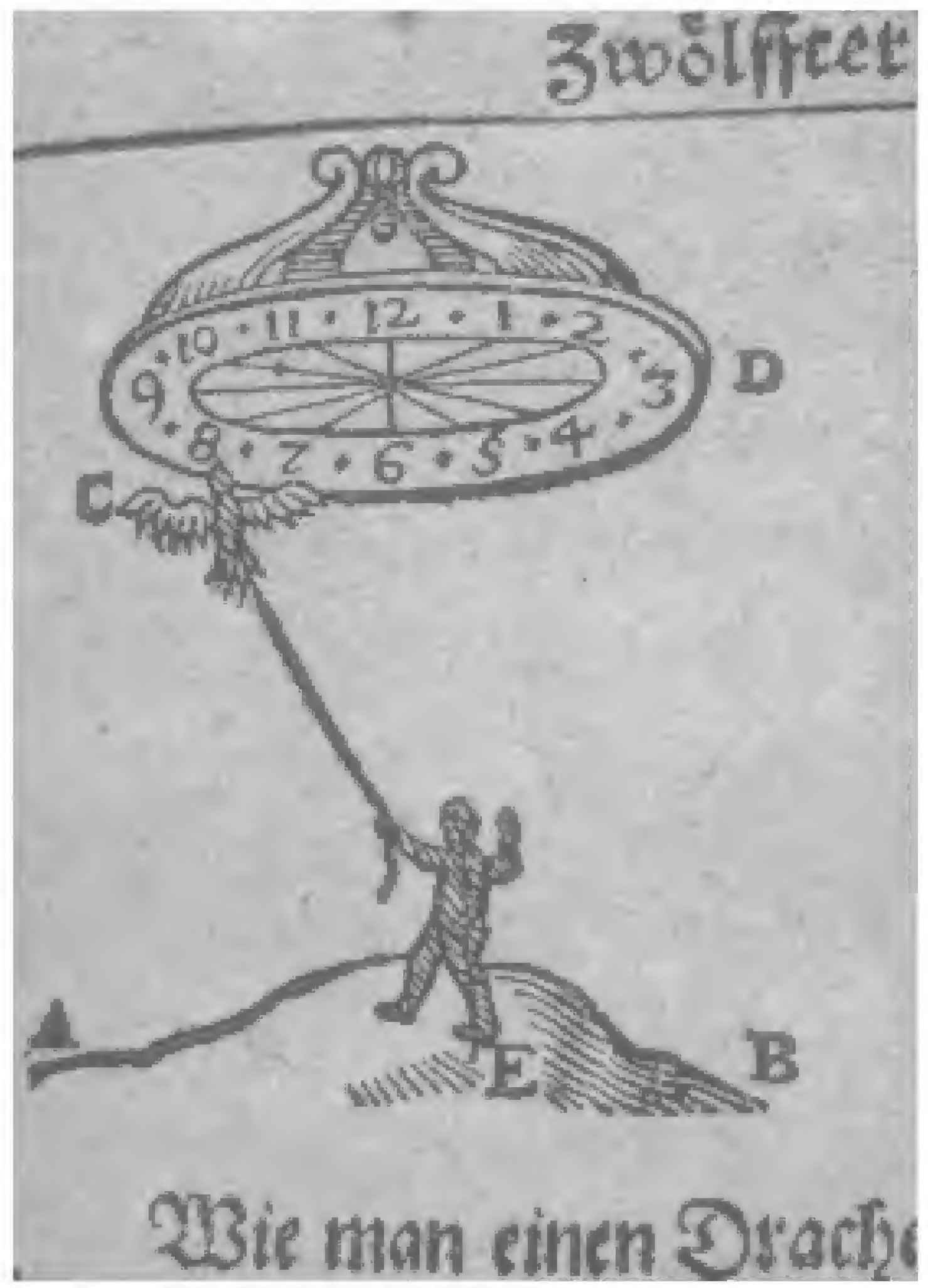

Archytas' magnetic bird, from Georg Philipp HarsdörVer's Delicia mathematica et physica, I677. 
the language and traditions of magic in sixteenth- and seventeenth-century Europe. A number of great historians have preceded me in this quest, from the brilliant literary scholar Rosalie Colie to the pioneering student of clockwork Otto Mayr. ${ }^{4}$ Most recently, William Eamon and Pamela Long have traced substantial parts of the complex network of intellectual and practical connections I want to reconstruct. 5 Nonetheless, I would argue the tradition of mathematical magic bulked larger and performed more duties than most historians have realized. In fact, it ended by being something like a foreign piece of mechanistic grit, imbedded in the organic magical world view of men like Ficino and Kircher, which stimulated the formation around it of some radical new ideas that came to be known, once generalized and transformed into a new intellectual program and method, as the New or Mechanical Philosophy.

As early as the thirteenth century, Roger Bacon, Petrus Peregrinus and others had called, in words that would ring down the centuries, for the creation of devices that could enhance the power and wealth of the human race: giant burning mirrors, vehicles that could move on their own, submarines and airplanes. Only the creation of what Bacon called a scientia experimentalis could realize these ambitious designs. Bacon also believed in the powers of natural magic in the more traditional sense. He argued that the letter from the Virgin Mary, which the leader of a popular rising, the Pastoureaux, had brandished, was in fact an astrological talisman, designed by Tartar astronomers bent on the destruction of Christendom, which enabled its owner to gather and deceive large crowds. But he made no connection between magical powers of this kind, which he rejected as illicit, and the scientia experimentalis, which he saw as so valuable that he described it in great detail in a letter to the pope. 
In the fifteenth century, however, both the status of magic and the claims of technology underwent metamorphoses. Clerics unprovided with benefices and learned men steeped in the magical traditions of the Islamic and Byzantine worlds began to write positively about magic, in a number of different forms. Traditional forms of magic, like the ars notoria, that early equivalent of Cliff Notes, offered their practitioners rapid and easy ways to do everything from gaining mastery of a scholarly subject to calling up demons who could frighten a patron — and suggested that he should rely on his court magician for help. More sophisticated forms of magic, based on ancient disciplines like astrology and the Cabala, enabled scholars at a higher level to offer their customers luxurious new regimens that would keep them healthy, enhancing their life force and protecting them from malevolent planets like Saturn. The greatest intellects proclaimed that natural magic - the form of magic that the ancient Jews and Chaldeans had practiced, and that married the heavens to the earth - was not a dangerous indulgence in traffic with devils but a profound and legitimate discipline. In a formulation that magicians would copy and recopy over the decades, Giovanni Pico della Mirandola proclaimed that magic of this kind represented the culmination, the consummation of all true philosophy. The learned magus had reappeared as a formidable figure in western society and thought. ${ }^{6}$

But the magus was not the only new figure of power to stalk the landscape of Europe in the fifteenth century. In Florence and Siena, Milan and Naples, engineers also flourished - engineers whom modern historians often identify, more one-sidedly than they would have identified themselves, as painters or architects. They included the still famous - like Filippo Brunelleschi, whose dome for the Florentine cathedral, built without central 
supports, seemed to Leon Battista Alberti so brilliant in conception as to disprove the myth that the minds of modern men were inferior to those of the ancients, and large enough in scale to cover the entire population of Tuscany. But they also included men less well known, like Mariano Taccola, a Sienese expert on hydraulics and military technology, who described his inventions in systematic, illustrated notebooks, and Georg Kyeser, a German military expert who did the same, even more resplendently.

These engineers were tasked by the communes and warlords who employed them, not only with practical jobs like making cannon and building fortifications, but also with what amounted to magical assignments. From the fourteenth century on, they built the great escapement clocks that automatically tolled bells to signify the passing of the hours in cities and monasteries, and sometimes turned wheels to indicate the movement of the planets. Engineers equipped these timepieces with magnificent "jacks" - automata, from the cock that crowed at the top of the Strasbourg cathedral clock, to remind all Christians of how Peter had betrayed his Savior, to the figures of death and the Three Magi that danced to the amazement of crowds, when the hour struck. Konrad Dasypodius, who redesigned the Strasbourg clock in I57I-74, explained that "these pneumatic devices and automata excite great wonder from ordinary people, when they hear music not made by men, or the crow of a cock. Such things may seem to have more to do with the fine-tuning of a project like this than with its absolute requirements, but it is the architect's job to see to it that the work is not only elegant and symmetrical in all its parts, but also appropriately attractive, and magnificent."7

The same engineers performed another vital service every time that a ruler entered a city subject to him, married off a child, 
or staged a triumph, or a city government or fraternity staged a similar show. To prove that the despots of little Renaissance cities had power over nature, as well as man, engineers built spectacular pageant wagons for them - wagons that moved without animals to pull them, as hidden teams of soldiers energetically cranked their wheels. To inspire awe in spectators at the mysteries, Brunelleschi made angels and the saviour himself fly on a mechanical mandorla. And again, they equipped their inventions with automata that moved on their own as if magically animated. In 1452 - just to give one example among dozens - when Borso d'Este, the ruler of Ferrara, entered Reggio, he was greeted by a magnificent wagon on which rode St. Prosper, patron saint of the city. A mechanical angel on the baldachino over his head dispensed blessings, while eight more danced in a circle, to the beat of a drum, at his feet.

The engineers who carried out these feats - like their rivals, the magicians - drew on ancient technologies: not spells, in this case, but the hydraulic and pneumatic technology of ancient Alexandria, which had been transmitted through the Islamic and Byzantine worlds to the west. But their attitude towards the world around them matters more than the sources they used. Engineers, like magicians, loved to amaze and frighten their audiences. Giovanni Fontana, the early fifteenth-century Paduan engineer who drew, among other things, the first illustration of a magic lantern, devised this system of projection in order, as he told his readers, to inspire terror. And he used his engineering skills to mimic the magicians' tours de force - as when, for example, he showed that by attaching articulated skeletons to a massive clockwork device, one could literally make the dead walk - exactly what necromancers claimed to do with their spells. Fontana was interested in other forms of magic, like as- 


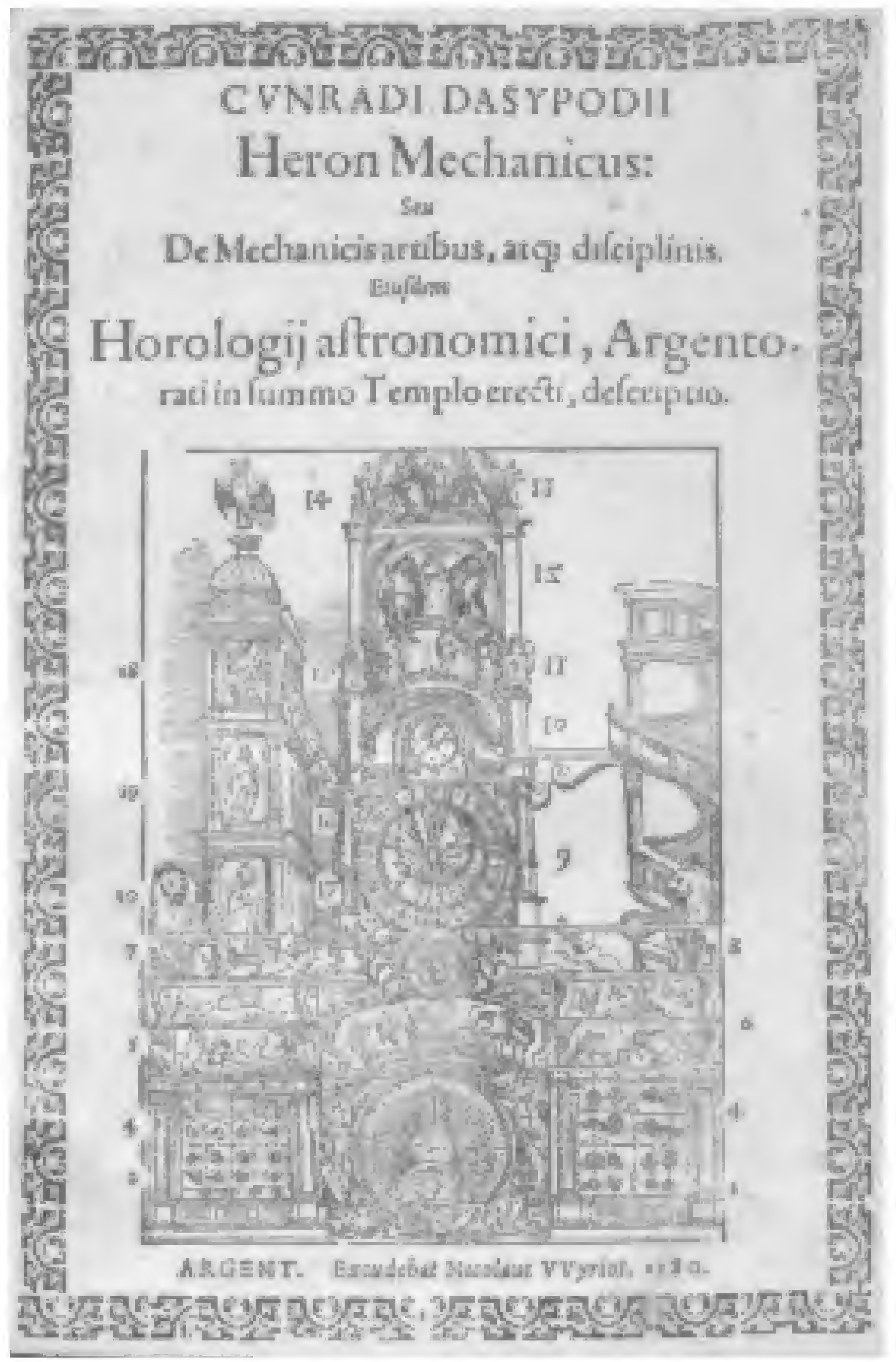

The cock at the top of the Strasbourg cathedral clock, from

Konrad Dasypodius' Heron mechanicus, seu, De mechanicis artibus, I580. 


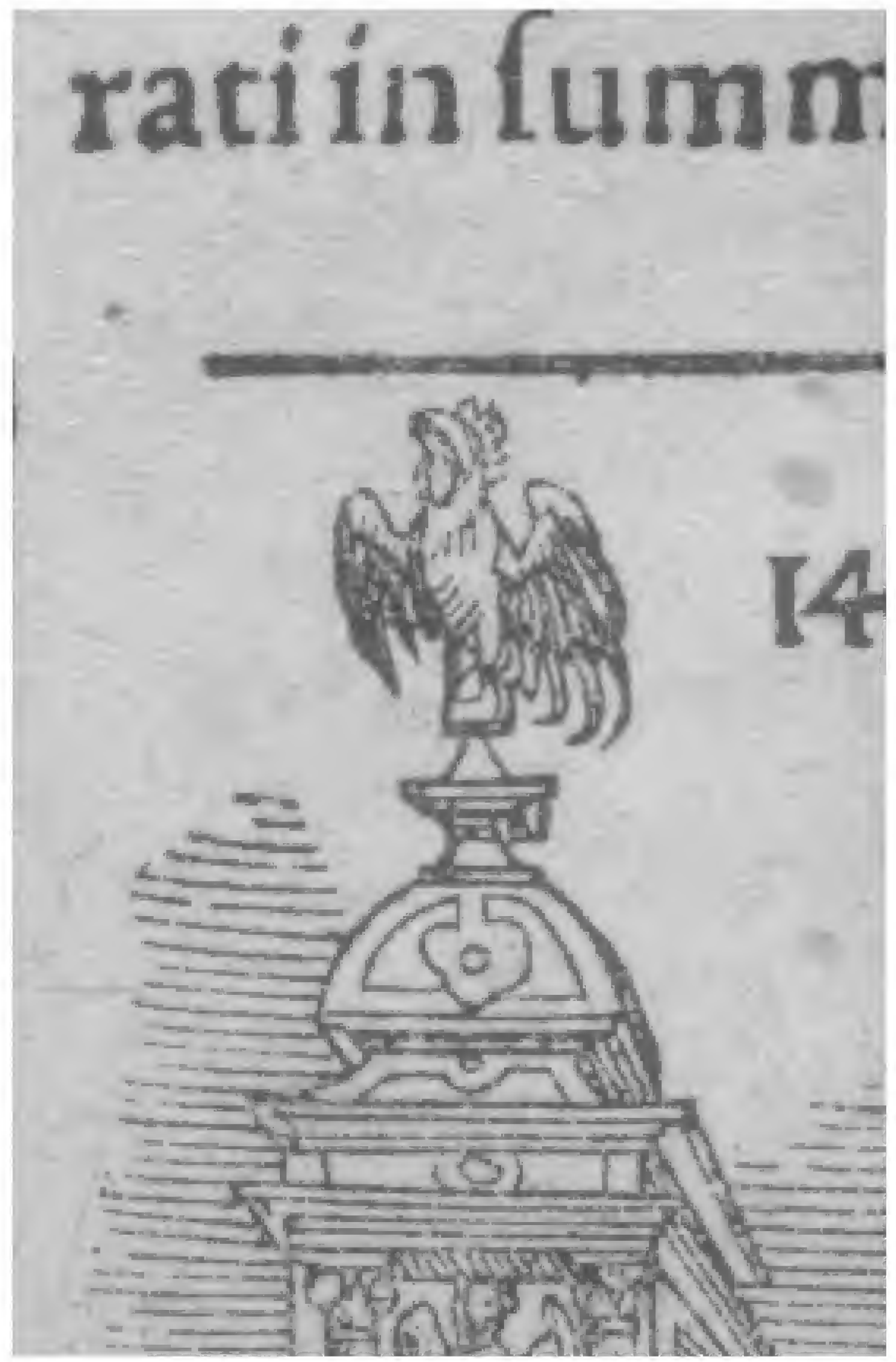

The cock at the top of the Strasbourg cathedral clock, detail from Konrad Dasypodius' Heron mechanicus, seu, De mechanicis artibus, I 580. 
trology and the ars notoria, which he described in detail in a strange encyclopedic work. For the most part, however, he took pride in applying his own technical skills to analyzing natural phenomena and creating artificial ones. Discussing the omens often sighted in fifteenth-century skies, and used to devastating political effect - armies marching, for example, in the clouds - he insisted that these were merely optical phenomena produced by the passage of sunlight through clouds. He even drew up a treatise on atmospheric perspective, which he presented to the painter Jacopo Bellini.

More formidably still, Fontana analyzed the characteristic motions of devils, and created automata that could mimic thesevery likely for plays or entries of the sort I have described. Modern scholars often note that early engineers did not supply formal working drawings of their devices, but represented them in real time, functioning, in a way that did not give away their secrets but could appeal to patrons. Fontana, however, makes a superb exception to this rule. It's true that he didn't show how to make my personal favorite among his military devices, the MontyPythonish fire-farting rabbit. But in other cases he was much more forthcoming. He drew not only male and female devils inspiring terror in real time by their fearsome appendages, but also the underlying mechanisms, which he laid out with the abstracting brilliance of a fifteenth-century Giacometti or Max Ernst. ${ }^{8}$ My learned associate Louise Grafton was in fact able to build, from Fontana's drawing, one of his automata: this magnificent female devil. As you will note, the strings controlling her movements work exactly as Fontana's drawing suggests they should.

Fontana insisted that he was no magus. When witnesses at Padua exclaimed that a torpedo he had designed must run by diabolic power, he refuted them with contempt: the device was 


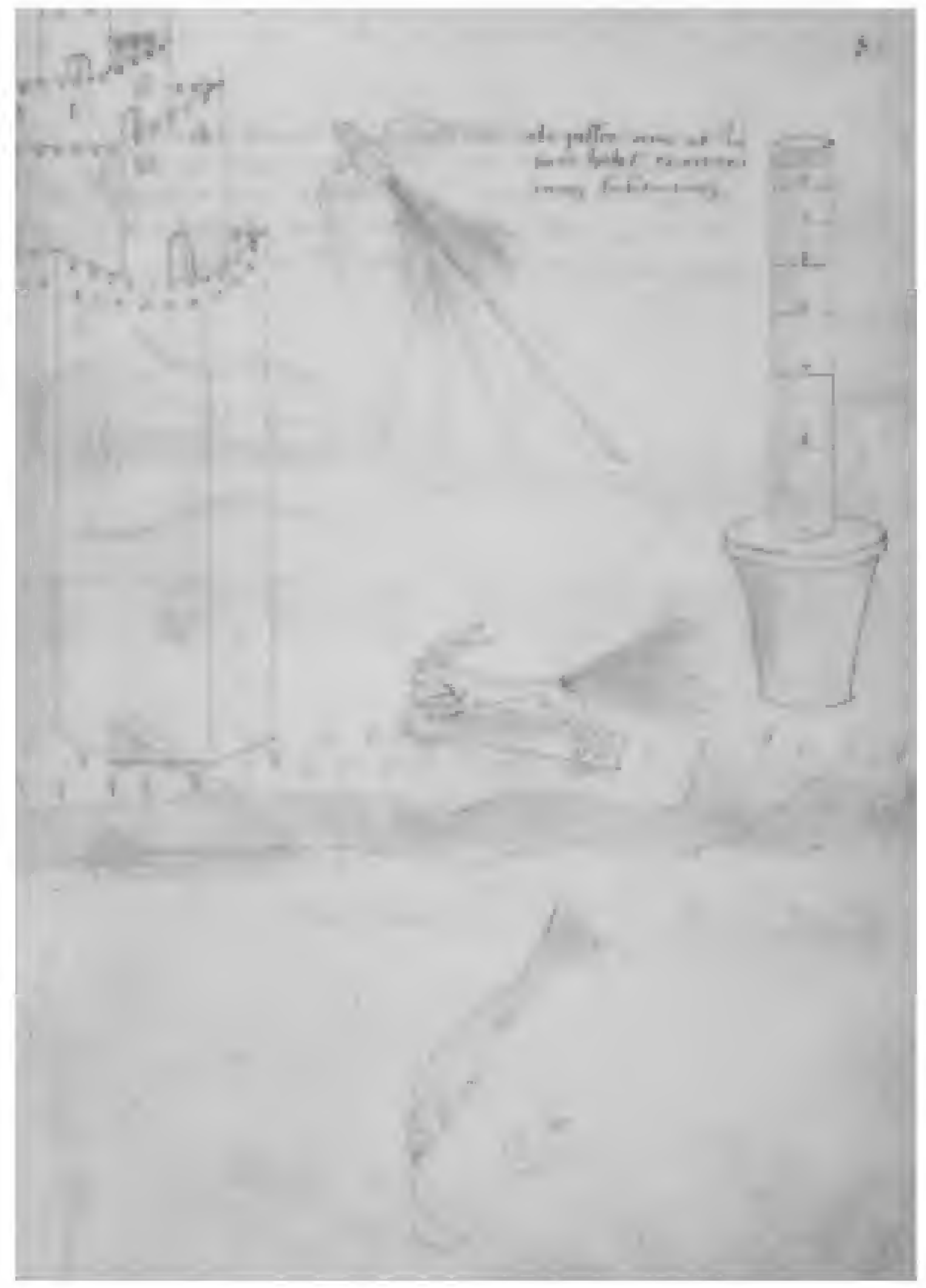

Rabbit, from Giovanni Fontana's Bellicorum instrumentorum, Cod.icon. 242, I420 (courtesy of the Bavarian State Library, Munich). 


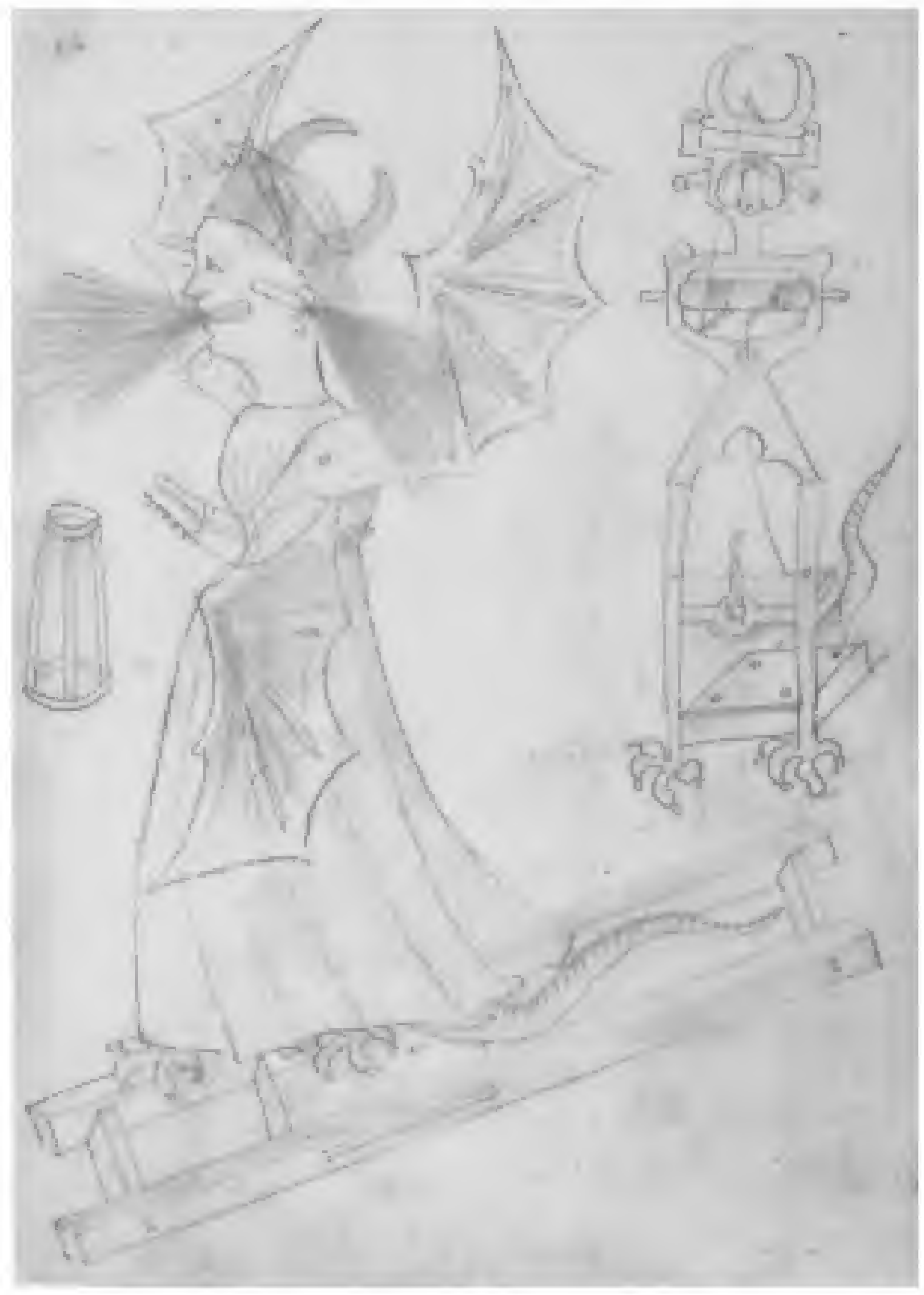

Female devil, from Giovanni Fontana's Bellicorum instrumentorum, Cod.icon. 242, I420 (courtesy of the Bavarian State Library, Munich). 
purely mechanical, as befitted a maker who was also a master of both medieval Archimedean statics and optics and of Renaissance engineering craft. But he challenged the magi at their characteristic sport, and made a brilliant job of doing so. No wonder that even some of the most prominent and bold of the Renaissance magi - like Marsilio Ficino - described the great clocks in Florence and other cities as models of the world and proofs, by analogy, of the existence of a creator. Even they could not ignore the challenge of the engineers. Around I 500, Leonardo da Vinci became celebrated across Italy, and then all of Europe, for his dazzling designs of tanks and mortars. He filled his notebooks with precise efforts to show that he could model the anatomy, and the motions, of the human body mechanically, and devised striking automata. In each of these ventures, he was carrying the work of earlier engineers to a new level of sophistication.

During the fifteenth century, even as engineers attained a new prominence and their pursuits reached a new level of sophistication, the situation of the magi became more delicate. The new theorists of witchcraft, like Kramer and Sprenger, saw devils lurking in every cowpod and millpond - and convinced Pope Innocent VIII that they were right. When Pico della Mirandola set out to argue, in a public disputation at Rome, for the thesis that natural magic could demonstrate the divinity of Christ, he found himself forbidden to proceed, expelled from the Vatican library and under investigation for heresy by a commission appointed by the scrupulous, magic-obsessed pope.

Just at this juncture, so it seems, men interested in both magic and engineering began to contemplate celebrating a marriage of the two traditions. Francesco Giorgi - a Venetian Franciscan who described the magical world picture at immense, eloquent length in a treatise on The Harmony of the Universe - was also an 
expert architect who consulted on acoustics and sightlines when new churches had to be built. In his treatise, he noted that the Egyptians had made statues that could speak, and Albertus Magnus a brazen head that could do the same; that Archytas of Tarentum had made a fiery dove that could fly, and Daedalus had used artificial wings to fly ("some of our contemporaries," Giorgi notes, "have done this for a short distance" - perhaps a reference to Leonardo). He connected these mostly classical stories of automata and marvelous vehicles with the claims of Roger Bacon, who, he said, had used "pure and natural magic" to create thunder, clouds and rain in the atmosphere and transmute certain substances. And he argued that these accomplishments like the most standard magicians' efforts to "apply active substances to passive ones" - all represented not, as ordinary folk thought, miracles, but "natural works" - a magic that, some of the time at least, created marvels without relying in any way on illicit powers, or even, for the most part, on knowledge of the occult qualities of things. 9

Giorgi left matters here; but his hint that magic could be natural in a new and different sense fell on very avid ears. As early as I 5 IO, the medical man and humanist Henry Cornelius Agrippa was at work on what he hoped would become the first systematic treatise of magic (or, as he called it, Occult Philosophy). He produced a first draft - a richly spiced gumbo of traditional recipes (cure a sore throat by swallowing a small green frog) and recent revelations from Hebrew manuscripts of the Cabala. But Agrippa lost confidence in the first version of his work, and suppressed it. Gradually, in fact, he lost confidence in most forms of magic. He refused to draw up horoscopes, and stuck to his guns at the cost of losing a court position. And he made fun of many forms of learned magic. 
In Italy after I 5 I2, Agrippa continued to study ancient magical and philosophical texts, even giving public lectures on Hermes Trismegistus. But he also pursued a second career, as military and civil engineer. In Milan or Pavia, he gained access to the circle of Leonardo da Vinci, and actually had the chance to see and copy diagrams from Leonardo's notebooks. Once he returned to northern Europe, he "was in charge of some of the imperial majesty's mines," as he recalled in I 529 . He knew and liked craftsmen (notably a drunken clockmaker named Tyrius); he drew up his own collection of drawings of war machines, as well as "a machine for projecting fiery globes, which has no rival for speed, ease or simplicity, and many other things like it." His expertise won him recognition. One friend remarked that Agrippa had shown him a mirror which made it possible "to tell the dead part from the living one in a painting" - a description that stimulates, but does not satisfy, the imagination.

By the end of the I520s, Agrippa was at last ready to publish: not his big treatise On Occult Philosophy but a short, biting satirical work On the Vanity of the Arts and Sciences. Here he denounced all of the traditional forms of magic, from astrology and alchemy to the Cabala, as so many kinds of imposture. But he also argued that a form of activity he called both "architecture" and "mathematical magic" really did give its votaries powerpower so immense that they could transform the physical world: Even without the aid of natural powers, works like natural ones can be produced from the mathematical disciplines alone, as Plato says: "not things that take part in truth and divinity, but certain simulacra related to them, like bodies that walk and speak even though they lack any animal virtue, like the statues and automata of Doedalus among the ancients, which Aristotle mentions ... To this category belong all the miracles of simulacra that are produced by geometry and optics... That is how mirrors are made, concave or convex, which 


\section{SOHENRICI COROS}

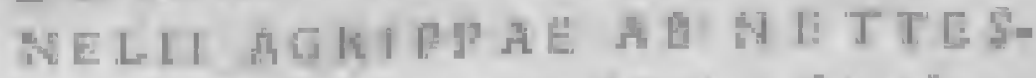

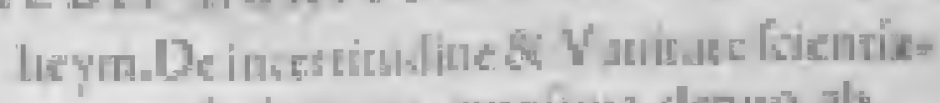

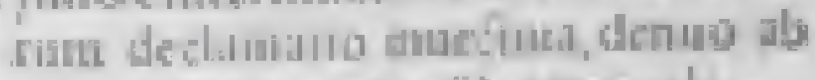

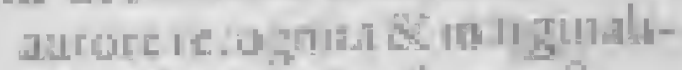

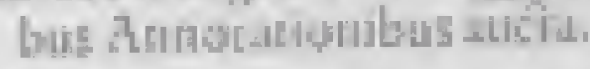

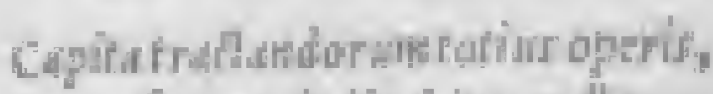

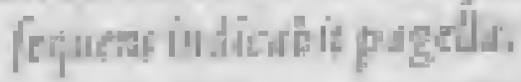

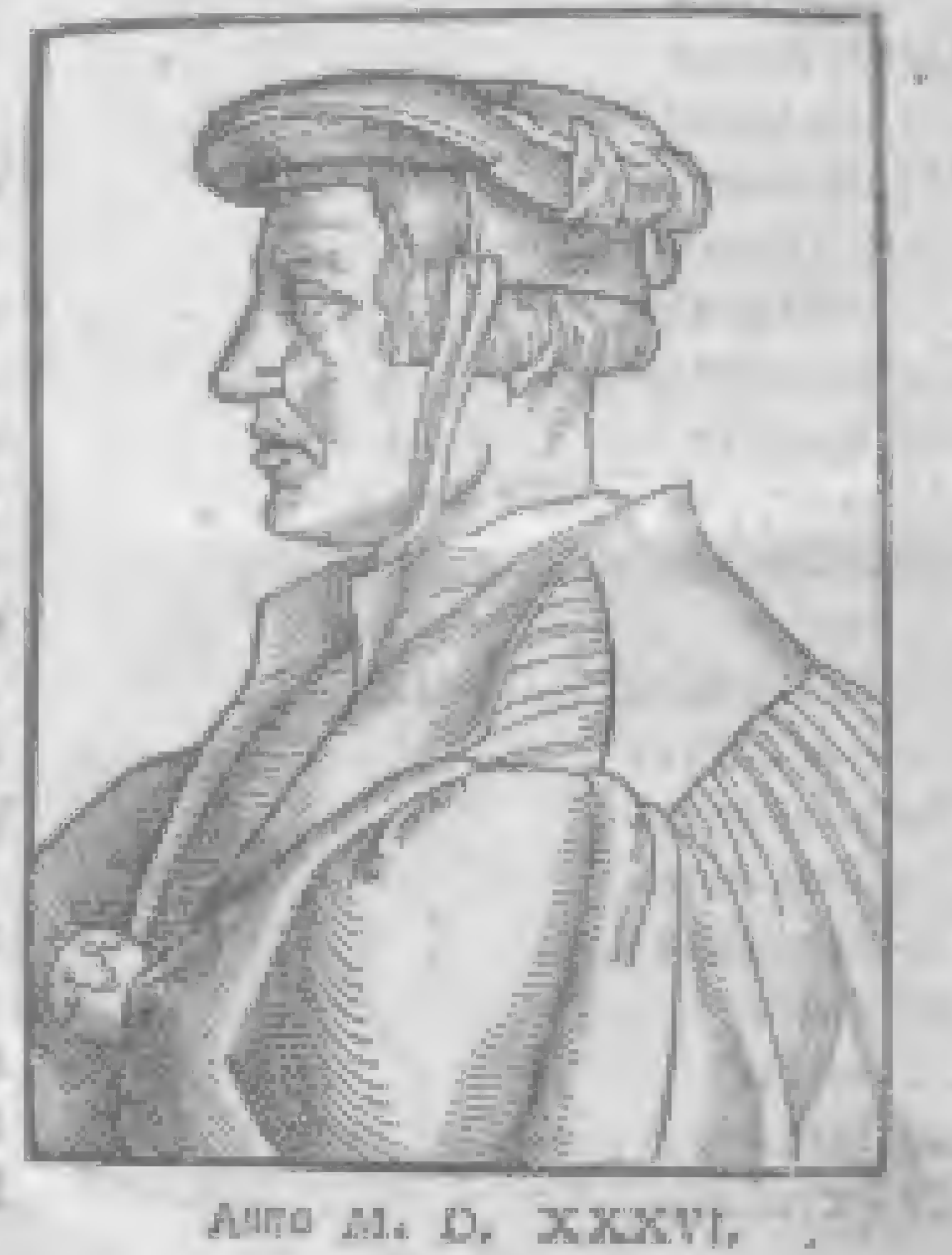

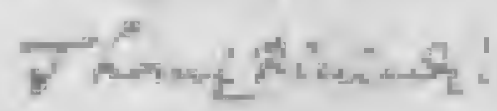

Profile of Henry Cornelius Agrippa from the I 536 edition of his De incertitudine $\mathcal{E}$ vanitate scientiarum. 
make images of things appear in the air at a great distance . . Hence the magus, who is a master of natural philosophy and mathematics, and knows the mixed sciences that consist of both of these, arithmetic, music, geometry, optics, astronomy, and the sciences of weights, measures, proportions and joints, and knows the mechanical arts that derive from these, can also, not surprisingly, work many wonders, which may astonish even the most prudent of men."

"All of these things," Agrippa admitted, seemed repugnant to the natural order. Hence the ignorant ascribed them to the work of demons. In fact, however, these transformations in or violations of - the natural order resulted from the application of natural and mathematical disciplines — and they had brought enormous gains to the human race. ${ }^{\text {1o }}$

As in so many other contexts, so here, Agrippa did not use his own words when he set out to speak in the language of the new technology. He took his examples of legitimate natural magic - the automata of Daedalus and the like - from Francesco Giorgi. And he adapted his praise of the power of these and similar mechanical devices from one of the most forceful and famous spokesmen of the engineering tradition, Leon Battista Alberti. In the prologue to his work On Architecture, the first modern treatise on the subject, Alberti had written that,

by cutting through rock, by tunneling through mountains and filling in valleys, by restraining the waters of the sea and lakes, and by draining marshes, through the building of ships, by altering the course and dredging the mouths of rivers, and through the construction of harbors and bridges, the architect has not only met the temporary needs of man, but also opened up new gateways to all the provinces of the world. ${ }^{\mathrm{II}}$

Agrippa quoted this passage word for word in his discussion of mathematical magic. His stay in Italy had not only made him acquainted with the new engineering and the older intellectual traditions of Bacon and Giorgi: it inspired him to see these pur- 
suits as the core of a legitimate and powerful magic. The new, mathematical magic that Agrippa encountered in Italy - the mechanistic, reductionist magic of the engineers - even restored his ebbing faith in occult philosophy. Eventually, he continued and completed On Occult Philosophy. And he included in it, once again, his paeans of praise to the new mathematical magic which, he thought, made clear that magi really could transform the natural world. The encounter with mathematical magic transformed Agrippa's vision of the field of the whole. That explains why an advocate of number mysticism and Cabala consummated the marriage of magic and engineering. The automata and optical devices that Fontana had portrayed as evidence of the superiority of his mechanistic, rational art were simply appropriated by the magi - as one segment of their art which clearly did yield practical results. Agrippa's book became the desk reference of all learned magicians, from John Dee to Tommaso Campanella and beyond. And every one of them imbibed from it the conviction that some forms of technology - burning mirrors, automata, vehicles that moved on their own and flying machines belonged to the realm of magic. ${ }^{12}$

Yet even as mathematical magic became a stable part of magical practices and beliefs, the context in which the magi worked was changing. In the course of the sixteenth century, automatic devices invaded the everyday life of the European elite. Craftsmen in Nuremberg and Augsburg, longstanding centers of metallurgy and clock making, loaded the groaning tables of Germany city patricians and French kings with magnificent machines that dramatically employed the reductionist methods and achievements of pioneers like Fontana. One favorite type was the ship deliberately wrought to challenge the distinction between nature, embodied in the waves and sea creatures on the device's bottom, 
and art, exemplified by the guns and musical instruments wielded by its miniature crew. As these ships lurched forwards down a vast oaken banquet table on wheels deliberately offset to mimic the effects of winds and currents, their tiny crews played drums and pipes and fired salutes. Not just princes and city governments, but every master of a great house could now display his ability to make dead matter move.

Machines became even more dramatically prominent in gardens - the magnificent gardens that became essential to villa culture in the most advanced centers of fifteenth-century social life, parts of Flanders and Italy, and developed in the sixteenth century into the chief wonders of the Roman and Tuscan hinterlands. As late as I 542, when Guillaume Philandrier published the first modern commentary on the ancient treatise on architecture by Virtruvius, this well-informed humanist and engineer had not seen anything to match the artificial singing "blackbirds," powered by hydraulic devices, that the Roman architect described: "In our day," Philandrier commented, "statues seem to walk not thanks to the power of water, as they did, but to that of hidden strings and cords. The Greeks called such little images 'string-puppets."'I3 In the next twenty years, however, the full range of Alexandrian hydraulic devices were recovered and put into action by specialist garden designers. Grottos, crusted with real and artificial shells, housed water-powered automata that danced, played musical instruments and sang. Meanwhile clever booby-traps drenched any visitor who dared to inspect a splendid statue. Enter the gardens of the Aldobrandini villa, Gaspar Schott told his readers, and you would see a Cyclops playing pan pipes and a Centaur blowing a trumpet, both powered by water. "Many," he went on, "attracted by the device of the Cyclops, look at it closely, and find themselves sud- 


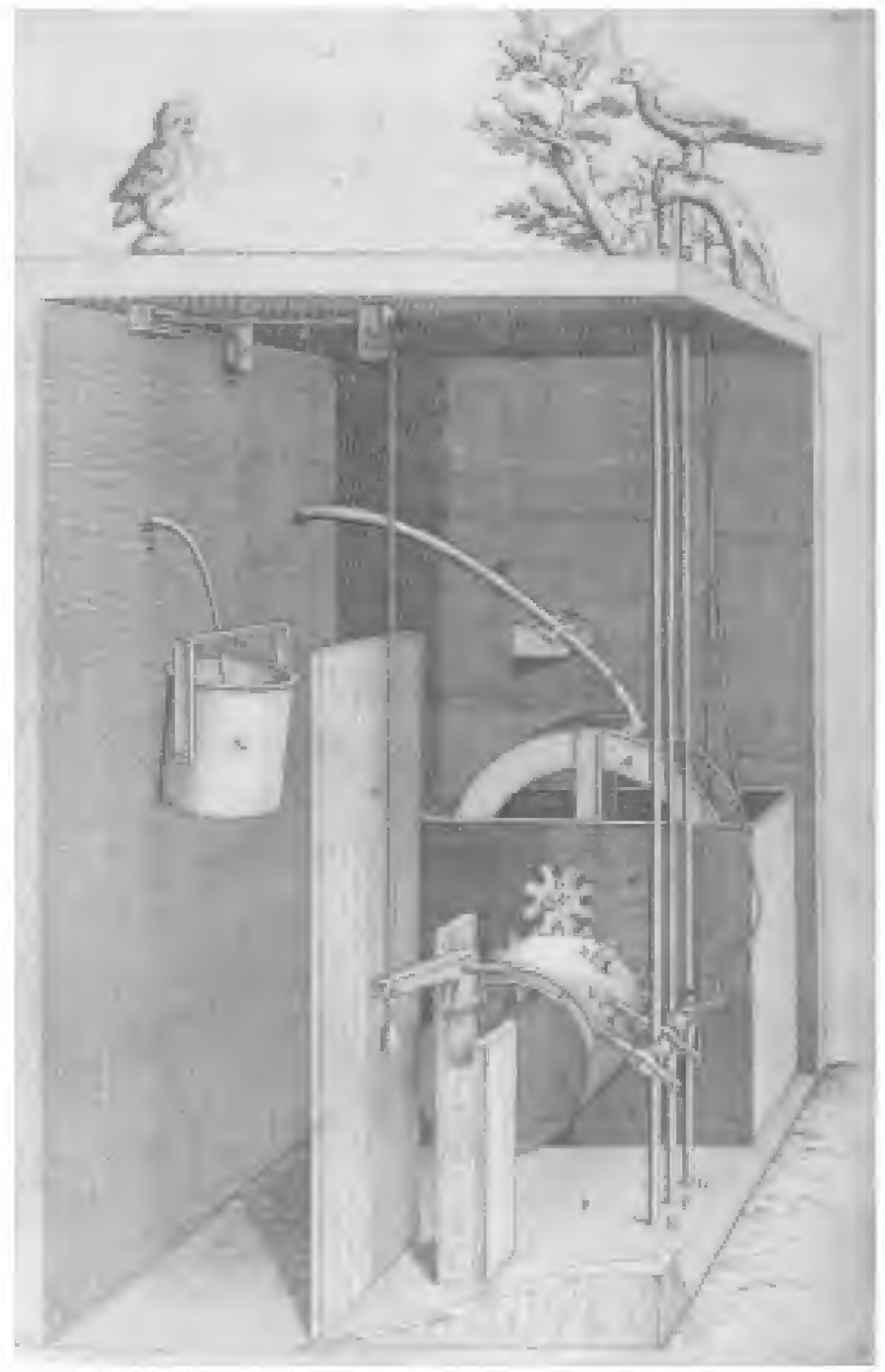

Artificial singing birds, from Salomon de Caus' Raisons des forces mouvantes avec diverses machines tant utiles que plaisantes, I6 55. 
denly drenched with water from hidden pipes. They are laughed at by spectators who know the trick in advance, and withdraw to safety." Even an innocent rose garden could reveal itself to be a hydraulic booby trap, every little statue of a bird or animals spraying the imprudent visitor who tried to flee. ${ }^{\mathrm{I}}$ The life of the European upper orders in the first age of "civilité" naturally rested on multiple games of humiliation, as Castiglione and della Casa made clear in their manuals of good conduct. But only an engineer or a mathematical magician could mechanize the upper-class putdown in so dramatic and effective a way. Reactions to these artful drenchings differed. Michel de Montaigne filled his diary of his trip to Italy with eloquent accounts of his experiences in hydraulically-adorned and booby-trapped gardens, which clearly struck his fancy every bit as much as the treasures of the Vatican library and the beauty of Rome's famous courtesans. But Cardinal Borromeo sourly informed his hosts, after a visit to such a garden, that they would have done better to spend the money on the religious orders that were undertaking missionary activity around the world.

Of all observers who set down their thoughts, the best-informed ones showed the highest enthusiasm. The sixteenth century, as Michael Mahoney, Giovanna Cifoletti and others have pointed out, saw a vast expansion not only in the techniques of learned mathematics, as Cardano, Tartaglia and others expounded new methods in formal Latin treatises, but also in propaganda about the importance of mathematical studies. ${ }^{\text {s }}$ Pierre de la Ramée or Petrus Ramus, the French educational theorist whose fiery denunciations of the Aristotelian curriculum made him at least in the eyes of his first modern historians - the lineal ancestor of John Dewey, insisted at length in his influential treatise on mathematics that Plato had been wrong to see it as a model 


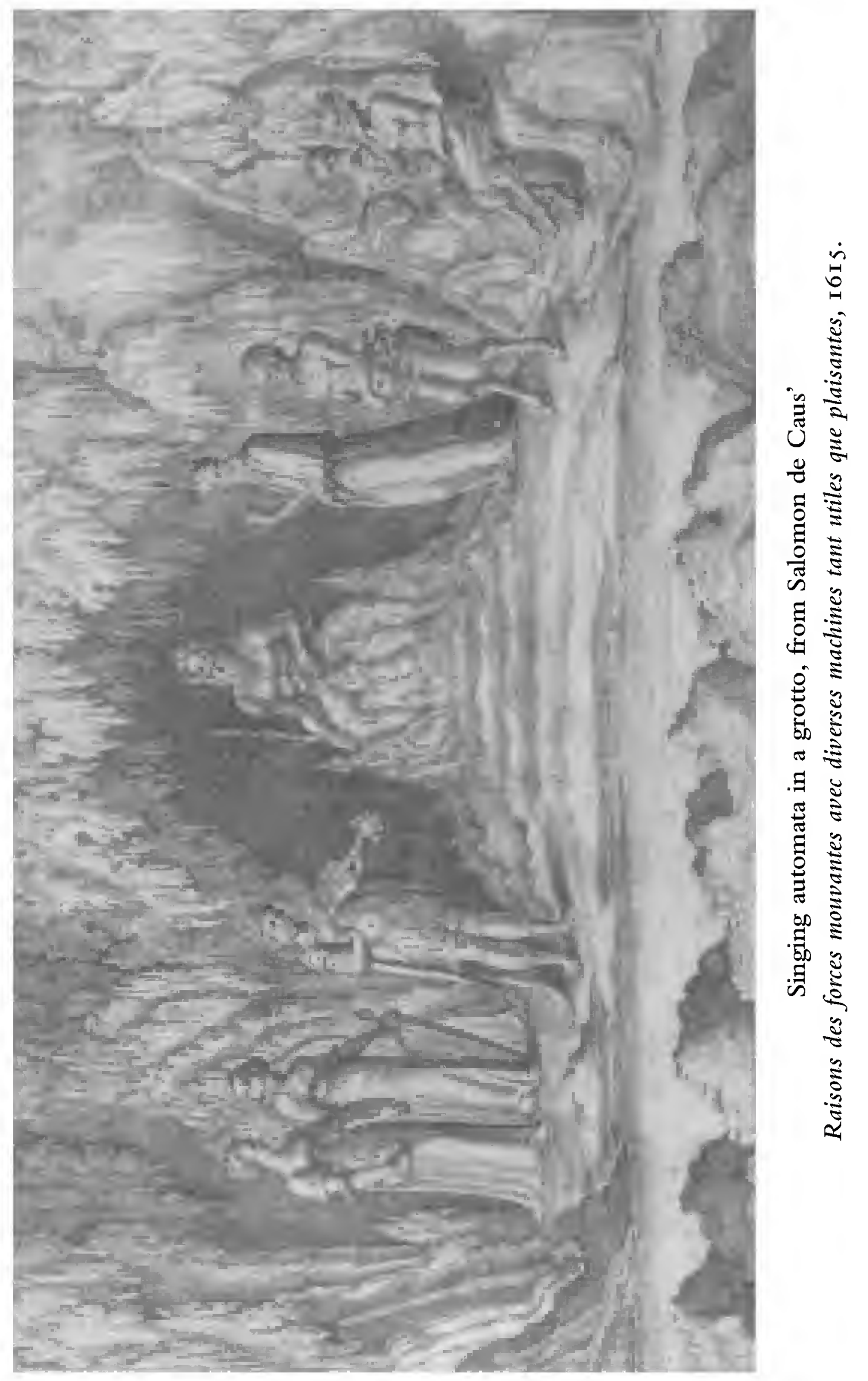


of abstract, pure intellection. Mathematics, Ramus insisted, had multiple applications in everyday life - a point he proved by laying out a spectacular panorama of the practical roles that mathematics played in the Paris of his own time, as bankers used it to change money, customs inspectors to impose duty, and exchequer officials to verify the royal accounts. The existence of automata, Ramus claimed, provided the most dramatic proof that mathematical techniques could affect the natural world. Drawing on Agrippa and other earlier writers, he listed ancient and modern automata - from the moving statues of Daedalus and the flying dove of Archytas through the talking head of Albertus Magnus to the bronze eagle and fly that Joannes Regiomontanus had crafted to welcome the Holy Roman Emperor to Nuremberg. ${ }^{\mathrm{I}}{ }^{6}$

Catholic proponents of the new mathematics often shared this radical Calvinist's enthusiasm for automata and similar devices. Adrianus Romanus, who enthusiastically drew up a textbook on ballistics, Mathesis polemica, for participants in the Dutch wars of the early seventeenth century, prefaced his work with an account of the branches of mathematics. Drawing on Geminus and Pappus, he wrote at length about what he called "thaumatopoetic" or "wonder-producing" mathematics — the branch of the discipline totally dedicated to instilling wonder and admiration. This category embraced, by his account, all devices that moved on their own, from Archimedes' spherical model of the universe to the large escapement clocks that, as he remarked, "can be found in virtually every city in the Low Countries." Like Francesco Giorgi and Agrippa long before him, Romanus was especially impressed by statues that seemed to move independently. He described at length "a silver goblet, in the form of a girl," that he had seen at Würzburg. This, he said: 
Could move down an entire table, however long it might be, to any guest, and when it came to the end of the table, it stopped, without making any further motion, as though it knew that it was nearing the end, and a precipice. Once the goblet was emptied and refilled, it could be sent to any other guests as well, in the same way, and it could continue moving for more than half an hour.

Others described automata in the imperial collection that could mimic their owner's gait and gestures, as well as his general appearance. ${ }^{\mathrm{r}} 7$

The ability to appreciate devices like these had become, by the early seventeenth century, part of the intellectual equipment that any up-to-date learned man had to be able to muster. And many did, to varying effects. Some validated the extraordinary powers of the magi and artificers who created startling new forms of automotive technology - another sector of mathematical magic, as you'll recall. When the great antiquary and observer of sun-spots, Nicolas Peiresc, visited the Netherlands, he made a special trip to Scheveningen to see a wagon powered by sails about which he had heard. Excited, he demanded to try a ride himself, and ever after, so his biographer Pierre Gassendi tells us, "he used to tell about the amazement by which he was seized, when, even though he was being propelled by a very strong wind, he did not feel any motion," and the riders he passed seemed to be moving backwards. ${ }^{18}$ Others were less impressed. Marin Mersenne reviewed the wonder-inspiring technology of his day in detail in his vast collection of philosophical and theological questions about the book of Genesis. But he did so in order to make clear that the automata human industry could produce were far too shaky in their movements, and worked for far too short a time, to simulate the appearances of angels and devils truly narrated in the Holy Scriptures. ${ }^{\text {I9 }}$

Eventually, continued exposure to mechanical devices - and 


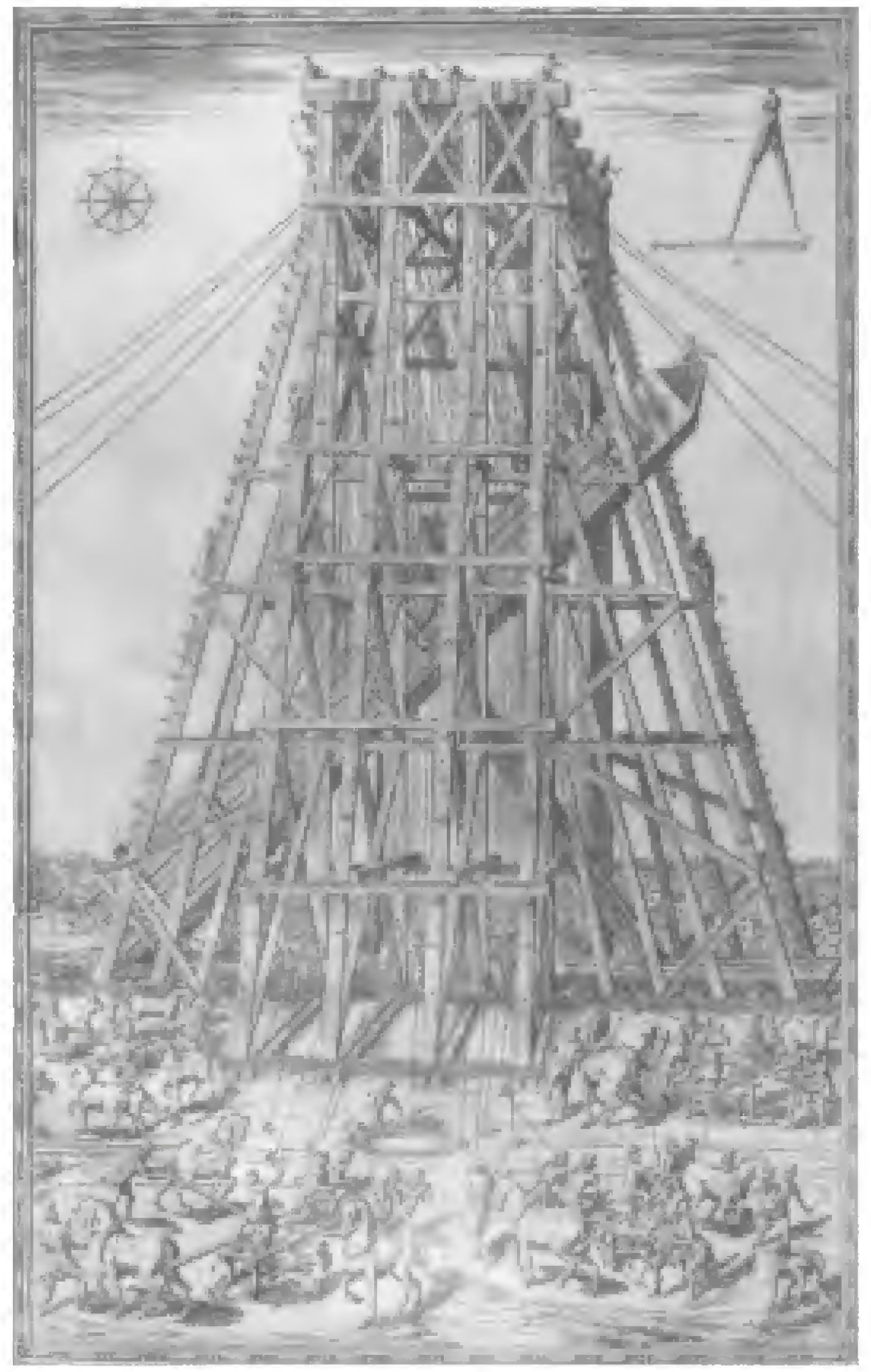

Transporting the Vatican obelisk, from Domenico Fontana's Della trasportatione dell'obelisco vaticano, I 590. 
continued efforts to master the heritage of Greek science leached the wonder from mathematical magic. The rediscovery of the Aristotelian Mechanics - a text that instructed readers on how to use machines to repair, and even to overcome, the forces of nature - suggested that there was nothing very magical about great machines. Even the most spectacular feats of late sixteenthcentury technology - like Domenico Fontana's transportation of the Vatican obelisk into the Piazza di S. Pietro - only illustrated the principles of this new science - as Henri de Monantheuil made clear in his commentary on the text. ${ }^{20}$ Other engineers, like Salomon de Caus, published detailed expositions of the machinery that powered the grottos and gardens of Italian villas - and made reference only to forces and machines as they did so. ${ }^{21}$

Some seventeenth-century connoisseurs of these devices continued to assign them to a form of magic. Schott and Wilkins were by no means the only informed contemporaries who assembled these and other instances of what we might call baroque technology under the heading of "mathematical magic." In fact, this title served to avert suspicion, not only from the performers in the Piazza Navona, but from the whole range of projectors who devised fountains and table settings, clocks and water organs. In particular, the Society of Jesus - the brilliant, expansionist religious order to which Schott belonged - adopted this idea for practical purposes. When Antonio Possevino, a major Jesuit scholar, produced his encyclopedic bibliography of all legitimate disciplines at the end of the sixteenth century, he condemned all forms of magic - but praised, and described at length, the wonder-inspiring garden machinery of the Roman villas that he liked to visit. ${ }^{22}$ Hostile readers could have seen a contradiction between the Jesuits' attack on diabolic magic and their defense of wonder- 
inspiring technology. So another Jesuit - one of their main authorities on the whole area, the biblical commentator Benito Pereira - dedicated part of an influential I 59I treatise to the subject. Pereira divided magic into three forms: illegitimate, diabolic magic; natural magic, which made licit use of the occult properties of things; that which he called "artificial" magic used clockwork and the simple machines to create automatic machinery and automobiles. This deft effort at classification - like many other Jesuit efforts at classifying everything from human sins to historical sources - proved as useful to Protestant as to Catholic learning. ${ }^{23}$ Both Wilkins and Schott, at their two respective ends of Europe's cultural and confessional divide, depended on Pereira for their understanding of what mathematical magic was, and of why its practice posed no threat to Christian society.

In the course of the seventeenth century, however, the kaleidoscope of intellectual opinion gradually shifted, especially in northern Europe, as devices multiplied to the point of tedium and clear explanations of them poured from the printing houses. Constantine Huygens owed his allegiance to the New Philosophy in part to his reading of Francis Bacon, but in equal part to the amazement inspired in him by the sight of Constantine Drebbel's "little ship, in which he calmly dove under water and thus held the king, his court and several thousand citizens of London in excited apprehension" for several hours. But his father's worried suggestion that Drebbel might be practicing diabolic magic made him laugh — as he reported in a letter to the aged parent at home in the Netherlands, in which he described how he had passed on this reproach to Drebbel "right into his beard," because he knew that it lacked any grounding. ${ }^{24}$ When Schott and Kircher talked of mathematical magic, they saw it as one subspecies of a larger set of pursuits, one that also included 
the exploitation of nature's secrets. When Wilkins talked of it, he did so in Huygens' spirit - as something that had no organic connection to magic in the traditional sense. Like Simon Stevin, he believed that "wonder is green [sic] wonder."

But a third - and most influential group - fell between the Jesuits and Huygens. Seventeenth-century philosophers, from Bacon onwards, hated the methods of magic - its use of secret languages, its appeal to occult powers. But they appreciated its claims to power over nature. And when they offered their readers power of the same sort, they did so in the terms of the mathematical magicians. And it was in this, new way that Descartes as a number of scholars have pointed out - seized on the garden automata of his time as illustrating a new, mechanistic understanding of the ways in which both human and animal bodies actually functioned.

The language of automata became part of a new way of describing not only the natural, but the human, world - as Thomas Hobbes showed, more effectively perhaps than anyone else, in the beginning of his Leviathan:

Nature (the Art whereby God hath made and governs the World) is by the Art of man, as in many other things, so in this also imitated, that it can make an Artificiall Animal. For seeing life is but a motion of Limbs, the beginning whereof is in some principal part within; why may we not say that all Automata (Engines that move themselves by springs and wheels as does as a watch) have an artificiall life? For what is the Heart, but a Spring; and the Nerves, but so many Strings; and the Joynts, but so many Wheeles, giving motion to the whole Body, such as was intended by the Artificer? Art goes further, imitating that Rationall and most excellent work of Nature, Man. For by Art is created that great Leviathan, called a COMMON-WEALth or StATE (in Latin CIVITAS) which is but an Artificiall Man; though of greater stature and strength than the Naturall, for whose protection and defense it was intended ... 25 
The billiard-ball social physics of Hobbes's state implied a new vision of the universe as well - one that had no space for magic in the traditional learned sense. But it was the characteristic devices of mathematical magic — the automata, with their mechanical vision of the human body and their capacity to evoke wonder - that made philosophers take an interest in technology.

Modern historians of the automaton - like Simon Schaffer and Gaby Wood, authors of two excellent, complementary accounts - usually connect the rise of automata with the rise of a new, mechanistic philosophy (as well as with new political and military conditions, like the creation of the well-ordered police state and the military revolution). ${ }^{26}$ These correlations are genuine; but they are also partial, a result of taking the seventeenth century's rhetoric of novelty and innovation too literally. In fact, as I have tried to show, both the automaton and the cluster of devices related to it and the mechanized understanding of the body that underpinned them grew up in a very different world - as only one constellation in a vast starry cosmos of theories and practices, which gradually came to outshine and dominate the rest. The great historian Frances Yates argued long ago that learned magic, with its promise of power over the world, was one part of the soil from which the New Science of the late sixteenth and seventeenth centuries grew. Many have corrected her, on points of detail too numerous to mention here. Yet on the main point, as so often, her instincts were sound. The particular delta where the two rivers of magic and technical practice came together in the fifteenth and sixteenth centuries turned into spectacularly fertile intellectual territory - and the grafting of magic and engineering that took place around isoo produced spectacular orchards, which in turn yielded remarkable new fruits. Tracing the intellectual genealogy of mathematical magic 


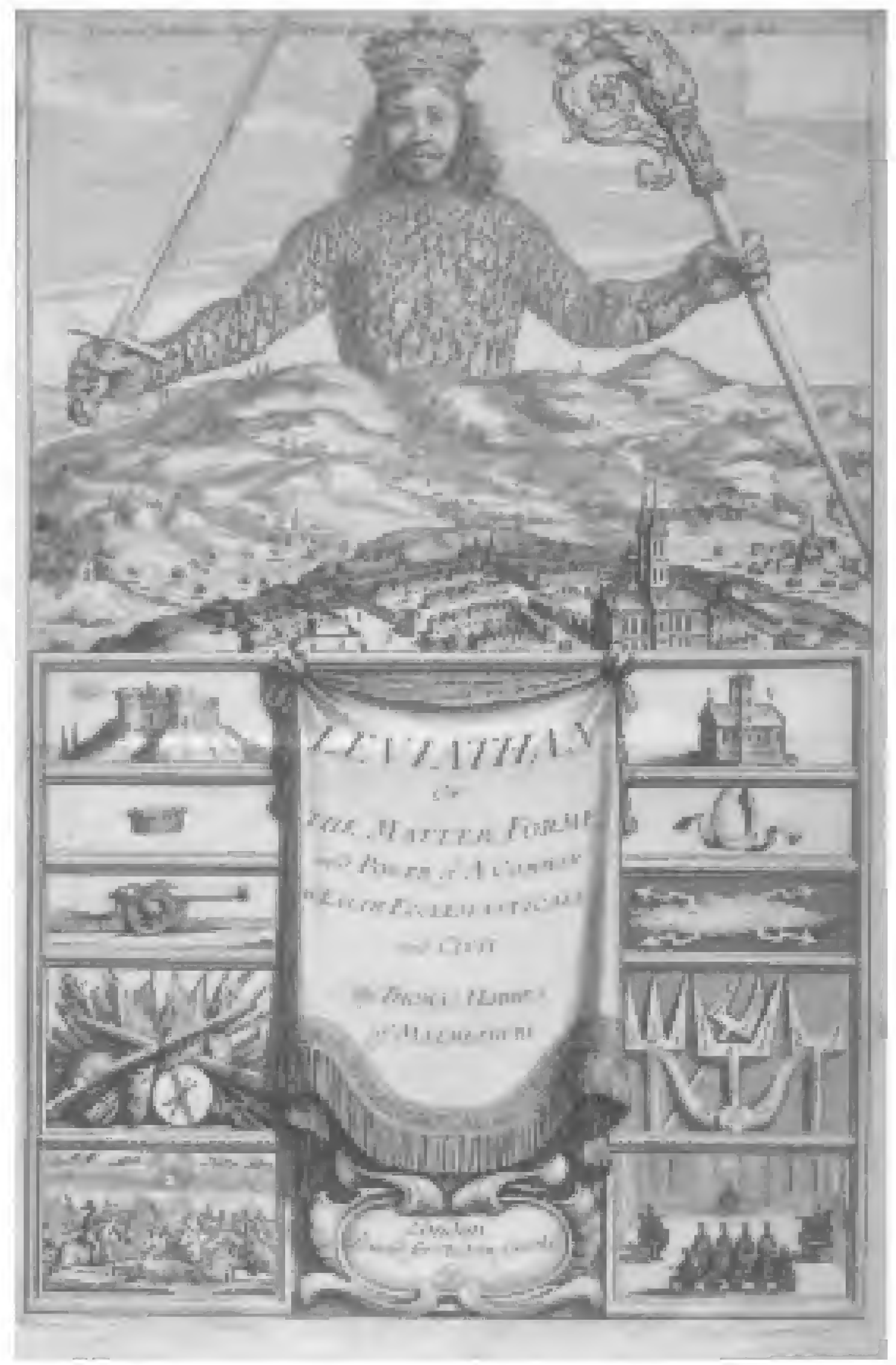

Frontispiece to Leviathan, Thomas Hobbes, I65I. 
is not a paper chase, but a way - the only one, I would argue to recover the forgotten cartographies of the intellectual globe that that apparent oxymoron once conveyed.

In the second part of the novel, Don Quixote, Cervantes's hero hears with astonishment the predictions uttered by a talking head, which a young magician wields as a very effective prop. Eventually, the hero learns that the head actually operates by a speaking tube, not by angelic or demonic agency. Yet he insists, at the end of the chapter, that the talking head had something magic about it. Twenty-first century readers are likely to see here, as elsewhere in the book, pure evidence of the hero's capacity for self-deception. In fact, of course, he was only giving voice to a period understanding of magic — one whose loss has made us insensitive to part of the magic of Cervantes's text, as well as to that of the fountains and automata that once upon a time evoked wonder from the blasé inhabitants of Europe's palace gardens and city squares. 


\section{NOTE S}

I Royer's story can be found in Gaspar Schott, Mechanica Hydraulico-Pneumatica (Würzburg: Pigrin, I657), 3 I I-2.

2 See, for example, Athanasius Kircher, Oedipus Aegyptiacus hoc est universalis hieroglyphicae veterum doctrinae temporum iniuria abolitae instauratio (Rome: Vitalis Mascardi; I652-I654) and Gaspar Schott, Magia Universalis (Würzburg: J. G. Schönwetter, I657).

3 John Wilkins, Mathematicall magick. Or, The wonders that may be performed by mechanicall geometry. In two books. Concerning mechanicall powers [and] motions. Being one of the most easie, pleasant, usefull, (and yet most neglected) part of mathematicks. Not before treated of in this language (London: S. Gellibrand, I648).

4 Rosalie Colie, Paradoxia Epidemica: the Renaissance Tradition of Paradox (Princeton: University Press, I966); Otto Mayr, Authority, liberty, \& automatic machinery in early modern Europe (Baltimore: Johns Hopkins University Press, I986).

5 William Eamon, Science and the Secrets of Nature: Books of Secrets in Medieval and Early Modern Culture (Princeton: Princeton University Press, 1994); Pamela O. Long, Openness, Secrecy, Authorship: Technical Arts and the Culture of Knowledge from Antiquity to the Renaissance (Baltimore: Johns Hopkins University Press, 2001).

6 Giovanni Pico della Mirandola, Oratio de hominis dignitate; Oration on the dignity of man; English translation by Elizabet Livermore Forbes (Lexington, Ky.: Anvil Press, 1953).

7 Konrad Dasypodius, Heron mechanicus, seu, De mechanicis artibus, atq[ue] disciplinis: eiusdem Horologij astronomici, Argentorati in summo templo erecti, descriptio (Strasbourg: Nicolaus Wyriot, I 580 ).

8 Giovanni Fontana, Eugenio Battisti, and Giuseppa Saccaro Battisti, Le macchine cifrate di Giovanni Fontana, (Milano: Arcadia Edizioni, 1984).

9 Francesco Giorgio, De harmonia mundi totius cantica tria (Venice: Bernardini de Vitalibus Calchographi, I 525 ).

Io Heinrich Cornelius Agrippa von Nettesheim, De incertitudine \& vanitate scientiarum E artium atq[ue] excellentia verbi Dei declamation (Antwerp: Joan. Grapheus, I530).

I I Leon Battista Alberti, De re aedificatoria (Florence: Nicolaus Laurentii, I485). 
I2 Heinrich Cornelius Agrippa von Nettesheim, De occulta philosophia libri tres (Cologne, I533).

I 3 Guillaume Philandrier, In decem libros M. Vitruvii Pollionis De architectura annotations (Rome: Andream Dossena, I 544).

I4 Schott, Mechanica Hydraulico-Pneumatica.

I5 Michael S. Mahoney, The mathematical career of Pierre de Fermat, 1601-1665 (Princeton, N.J.: Princeton University Press, I994; Giovanna C. Cifoletti, “La 'question' de l'alge_bre: Mathe_matiques et rhe_torique des hommes de droit dans la France du i6e sie_cle," Annales: E_conomies, Socie_te_s, Civilisations 1995, 50: 1385-1416.

I6 Petrus Ramus, Scholarum mathematicarum libri unus et triginta (Basel: Eusebium Episcopium, I 569).

I7 Adrien Romain, Mathesis polemica (Frankfurt: Levinus Hulsius, I605).

I 8 Pierre Gassendi, Viri illustris Nicolai Claudii Fabricii de Peiresc, senatoris Aquisextiensis, vita: (The Hague: A. Vlacq, I65I).

19 Marin Mersenne, Qucstiones celeberrimce in Genesim, cum accurata textus explicatione (Paris: Sebastiani Cramoisy, I623).

20 Henri de Monantheuil, Aristotelis Mechanica (Paris: Jeremiah Perier, I 599).

2 I Isaac de Caus, Salomon de Caus, and John Leak, New and Rare Inventions of Water-Works Shewing the Easiest waies to Raise Water Higher then the Spring (London: Joseph Moxon, I659).

22 Antonio Possevino, Bibliotheca selecta: qua agitur de ratione studiorum in historia, in disciplinis, in salute omnium procuranda (Rome: Typographia Apostolica Vaticana, I 593).

23 Benito Pereira, Adversus fallaces et superstitiosas artes; id est, De magia, de observationes somniorum, \& de divinatione astrologica (Ingolstadt: Davidis Sartorii, I59I).

24 Constantijn Huygens, De briefwisseling van Constantijn Huygens, 1608-1697 (Jacob Adolf Worp, ed. The Hague: M. Nijhoff, I9I I).

25 Thomas Hobbes, Leviathan; or, The matter, forme, and power of a commonwealth, ecclesiasticall and civill (London: A. Crooke, I65I).

26 Simon Schaffer, "Enlightened automata," In Sciences in Enlightened Europe, William Clark (et al., eds.), (Chicago: Univ. of Chicago Press, I999), p.I26-I65; Gaby Wood, Living dolls: a magical history of the quest for mechanical life (London: Faber and Faber, 2002). 


\section{L L U S T R A T I O N S}

PAGE 8: Title page of Schott's Mechanica hydraulico-pneumatica, I657.

PAGE I 3: Kircher's sunflower clock, from his Magnes; sive, De arte magnetica, I64I.

PAGE I4: Wind-powered wagon from John Wilkins' Mathematicall magick, 1648.

PAGE I 5: Vomiting lobster (figure VI) from Schott's Mechanica hydraulicopneumatica, I657.

PAGE I6: Mother of the Gods; from Kircher's Physiologia Kircheriana experimentalis, I680.

PAGE I9: Cat piano (figure II) from Schott's Magia universalis, i657.

PAGE 20: Archytas' magnetic bird, from Georg Philipp Harsdörffer's Delicice mathematica et physica, 1677.

PAGE 2I AND 22: The cock at the top of the Strasbourg cathedral clock, from Konrad Dasypodius' Heron mechanicus, seu, De mechanicis artibus, I 580 .

PAGE 28: Rabbit, from Giovanni Fontana's Bellicorum instrumentorum, Cod.icon. 242, I420 (courtesy of the Bavarian State Library, Munich).

PAGE 29: Female devil, from Giovanni Fontana's Bellicorum instrumentorum, Cod.icon. 242, I 420 (courtesy of the Bavarian State Library, Munich).

PAGE 33: Profile of Henry Cornelius Agrippa from the I 536 edition of his De incertitudine $\mathcal{E}$ vanitate scientiarum.

PAge 34: Artificial singing birds, from Salomon de Caus' Raisons des forces mouvantes avec diverses machines tant utiles que plaisantes, I6I 5 .

PAGE 39: Singing automata in a grotto, from Salomon de Caus' Raisons des forces mouvantes avec diverses machines tant utiles que plaisantes, I6 I5.

PAGE 42: Transporting the Vatican obelisk, from Domenico Fontana's

Della trasportatione dell'obelisco vaticano, I 590.

PAGE 47: Frontispiece to Leviathan, Thomas Hobbes, I65I. 
The text of Magic and Technology in Early Modern Europe was composed in Bembo, a typeface originally cut by Francesco Griffo in I 495 for the Venetian printer Aldus Manutius to publish De Aetna, by Cardinal Pietro Bembo. Griffo is often considered as the first type-designer, because his classic letterforms were devised specifically for the mechanical craft of printing, rather than as an imitation of scribal lettering. In I929 Stanley Morison oversaw the design of Bembo for machine composition, for Monotype Corporation. Bembo has since been accepted as one of the best book typefaces ever produced - admired as a classic, elegant renaissance font with its well-proportioned letterforms and functional serifs - it was redrawn especially to be readable in a wide range of sizes. 


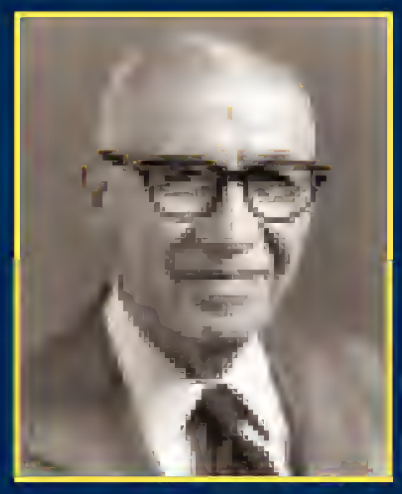

THE APPROXIMATELY IO,OOO VOLUMES of rare books and 10,000 manuscripts in science and technology originally donated by the Burndy Library to the Smithsonian Institution Libraries form the core of the Dibner Library's collection. Over the years, the book collection has been supplemented by the Smithsonian's own holdings and gifts from individuals and institutions, and now numbers some 30,000 rare books. The Dibner Library's holdings are contained within and searchable via the Smithsonian Institution Libraries' online catalog, SIRIS.

\section{H ER A L D S O F S C I E N C E}

The most widely recognized portion of the Dibner Library are the "Heralds of Science," 200 works selected by Bern Dibner as the most significant titles in the formation and development of Western science and technology. They were presented in his classic book, Heralds of Science (Norwalk, Conn.: Burndy Library, I955; reprinted in 1969 by Cambridge, Mass.: MIT Press; revised edition in 1980 by Burndy Library and Washington, DC: Smithsonian Institution). Dibner came up with eleven general categories and briefly described his choices of the greatest works that represented those disciplines. The Smithsonian Institution Libraries is in the process of constructing a web page that will describe the Heralds in greater detail. The works described in Heralds of Science continue to stand as major milestones in the history of science and technology. The publication is frequently cited in rare book catalogs (a particular volume is always referred to by its Heralds number) and is a tribute to the vision of Bern Dibner. 
